\title{
Hydrochemistry and microbialites of the alkaline crater lake Alchichica, Mexico
}

\author{
Józef Kaźmierczak · Stephan Kempe • \\ Barbara Kremer • Purificación López-García • \\ David Moreira $\cdot$ Rosaluz Tavera
}

Received: 28 May 2010/Accepted: 21 December 2010/Published online: 30 January 2011

(C) The Author(s) 2011. This article is published with open access at Springerlink.com

\begin{abstract}
The structure, mineralogy, and accretion processes of the modern and subfossil cyanobacterial microbialites from the alkaline crater lake Alchichica (Puebla, Mexico) were studied, along the lake's bathymetry and hydrochemistry. The recent lowering of the lake level had exposed microbialitic carbonate mounds and crusts, which emerged up to $2 \mathrm{~m}$ above the water surface, while accreting cyanobacterial microbialites were present down to a depth of $\sim 15 \mathrm{~m}$. Morphological and molecular analysis found that the living cyanobacterial mats were composed of diverse filamentous and coccoid cyanobacteria (Nostocales, Chroococcales, Oscillatoriales, and Pleurocapsales). The emerged subfossil microbialites comprised two generations: "white" (domes and crusts composed mainly of hydromagnesite with an admixture of huntite and calcite, ${ }^{238} \mathrm{U} /{ }^{230} \mathrm{Th}$ age of $\sim 2.8 \mathrm{ka} \mathrm{BP}$ ), and "brown" (chimneys, columns and laminated crusts composed of aragonite with an admixture of Mg-calcite, ${ }^{238} \mathrm{U} /{ }^{230} \mathrm{Th}$ age of $\sim 1.1 \mathrm{ka}$ BP). The significant age, structural, mineralogical, and
\end{abstract}

J. Kaźmierczak $(\bowtie) \cdot$ B. Kremer

Institute of Paleobiology, Polish Academy of Sciences, Twarda

51-55, 00-818 Warszawa, Poland

e-mail: jkaz@twarda.pan.pl

S. Kempe

Institut für Angewandte Geowissenschaften, Technische

Universität Darmstadt, Schnittspahnstr. 9, 64287 Darmstadt, Germany

P. López-García · D. Moreira

Unité d'Ecologie, Systématique et Evolution, CNRS UMR,

8079, Université Paris-Sud, bât. 360, 91405 Orsay Cedex, France

R. Tavera

Departamento de Ecologia y Recursos Naturales,

Facultad de Ciencias, UNAM, Mexico City,

A.P. 70-474, 04510 CU Coyoacan, DF, Mexico isotopic differences suggest that the two generations were formed in different environmental conditions: the "white" during a dry period, and the "brown" in wet climate associated with high water level and intense inflow of ground water, which lowered the $\mathrm{Mg} / \mathrm{Ca}$ ratio resulting in formation of aragonite instead of hydromagnesite. The hydromagnesite, replacing the primary aragonite precipitated in the living cyanobacterial biofilm, frequently undergoes silicification, which obliterates both the primary structure of the carbonate and the enclosed remains of cyanobacterial microbiota. This process helps to explain the abundant formation of dolomites and cherts in an allegedly highly alkaline Early Precambrian ocean. Thus, Lake Alchichica represents a modern alkaline environment where biosedimentary structures resembling Precambrian deposits are generated.

Keywords Microbialites - Cyanobacteria . Hydromagnesite $\cdot$ Molecular taxonomy - Carbonate chemistry $\cdot$ Lake Alchichica $\cdot$ Mexico

\section{Introduction}

Carbonate rocks are important components of marine deposits throughout Earth's history. The process of their formation significantly influenced the chemical evolution of atmosphere and hydrosphere, and, consequently, biosphere evolution (e.g., Holland 1984; Kempe and Degens 1985; Kempe and Kazmierczak 1994; Lowe and Tice 2004; Ohmoto 2004). Archean carbonate deposits enclose only few remains of microorganisms, which nevertheless indicate that microbial ecosystems, for example cyanobacterial mats, were involved in their origin (e.g., Walter 1983; Kazmierczak and Altermann 2002; Altermann and 
Kazmierczak 2003; Kazmierczak et al. 2004, 2009; Altermann et al. 2006). However, due to the lack of relevant modern analogues, the genesis of such deposits remains unclear. This concerns particularly the origins of diverse microstructurally laminated Precambrian biosedimentary structures called "stromatolites" and non-laminated finegrained (micritic) carbonates known as "thrombolites" (e.g., Bertrand-Sarfati 1976; Semikhatov et al. 1979; Buick et al. 1981; Kennard and James 1986; Grotzinger and Rothman 1996; Riding 2000; Kazmierczak et al. 2009). Papers presenting potential modern analogues of Precambrian microbialites (e.g., Fairchild 1991; Kazmierczak et al. 2004; Kazmierczak and Kempe 2006) are still rare, and, in spite of intensive efforts, far from solving the basic problems of stromatolite morphogenesis. The usage of these biostructures for paleoenvironmental interpretations is therefore still limited (e.g., Ginsburg 1991; Grotzinger and Knoll 1999; Sprachta et al. 2001; Dupraz et al. 2004). Direct comparisons of fossil and modern microbialites on a microstructural and ultrastructural level (e.g., Reid et al. 2003; Kühl et al. 2003; López-García et al. 2005; Benzerara et al. 2006; Bisset et al. 2008) are particularly rare, despite wide acknowledgment of their fundamental importance for deciphering the genesis of microbial carbonate deposits and the evolution of the early biosphere.

To fill this gap, in this paper we investigate the structure and growth processes (accretion) of modern cyanobacterial microbialites (particularly stromatolites) from the alkaline crater lake Alchichica (Puebla State, Mexico) in the context of lake hydrochemistry (and the carbonate system in particular). We hope that our results will help in reconstructing the environment in which fossil microbialites, known to occur abundantly in the lithological record (particularly in Precambrian marine formations), thrived.

\section{Materials and methods}

Location and geology

Alchichica is a crater lake (Laguna de Alchichica) located in the Cuenca de Oriental region $\left(19^{\circ} 24^{\prime} \mathrm{N}\right.$ and $\left.98^{\circ} 24^{\prime} \mathrm{W}\right)$, at the borders of the states Puebla, Tlaxcala, and Veracruz (Central Mexican Plateau), at an altitude of 2,300 $\mathrm{m}$ a.s.1. The crater is surrounded by an asymmetric tuff ring (Figs. 1 and 2). Arredondo-Figueroa et al. (1983) and Vilaclara et al. (1993) studied the bathymetry of the lake. It is over $60 \mathrm{~m}$ deep and bowl-shaped with a somewhat steeper slope at the southeast. Alchichica is the deepest crater lake in Mexico.

Geologically, Alchichica belongs to the system of salty endorheic lakes of the southern Trans-Mexican-Volcanic Belt. Besides Alchichica, five other neighboring crater lakes belong to this system: Quechulac, La Preciosa, Atexcac, Tecuitlapa, and Aljojuca. More details concerning the location, bathymetry, and limnobotanic characteristics of these lakes can be found in Alcocer and Hammer (1998); Vilaclara et al. (1993); Caballero et al. (2003); Armienta et al. (2008). Four of these lakes are located in the region Los Llanos de San Juan, and the other two in the region Los Llanos de San Andrés. Administratively, all belong to the northern part of the Puebla state.

\section{Hydrophysics and hydrochemistry}

We resurveyed the bathymetry of the crater lake of Alchichica using a combination of a battery-powered echosounder (Furano FE 600) and a handheld GPS (Garmin 12). From a rubber dinghy, 25 tracks, representing about 1,400 soundings, were recorded following the perimeter of the lake in a star-shaped pattern (Fig. 1d). From this dataset, 10-m isobaths were constructed (courtesy Nils Jansen; ArcGIS software). The greatest depth recorded was $66 \mathrm{~m}$ in the $\mathrm{NE}$ of the lake. Most of the bottom of the lake forms a plain between the depths of 60 and $65 \mathrm{~m}$. In general, the underwater sections of the crater wall are relatively regular with the exception of an area to the west where we found several pinnacles and hummocks. The constructed map differs significantly from the one published earlier by Vilaclara et al. (1993; their Fig. 1a). There, the crater lake was shown to contain large platforms separated by three NW-SE-striking depressions as if three faults dissected the lake. Volumes and areas obtained from integrating our new map are given for $10-\mathrm{m}$ intervals in Table 1. The area is significantly larger than reported before (i.e., $2.26 \mathrm{~km}^{2}$ compared to $1.8 \mathrm{~km}^{2}$ reported by Armienta et al. 2008). The volume amounts to just over $0.1 \mathrm{~km}^{3}$. The area-to-depth and volume-to-depth functions are given in Fig. 3a, b.

On June 19, 20, 2007, we took eight water samples $(0$, $10,20,26,30,40,50$, and $60 \mathrm{~m}$ depth) from the lake with the use of the dinghy, a rope, and a 5-1 Niskin water sampler. In addition, we took one sample from the groundwater draining into the lake at the bank of one of the lagoons on the western side of the lake ("seepage" sample), and a near-shore surface sample of the nearby crater lake, Lake Atexcac (Fig. 1), close to where the path reaches the lake. Temperature, $\mathrm{pH}$, and conductivity were measured in the water bottle immediately after it was retrieved using a WTW MultiLab P5 and a pH-electrode Meinsberger EGA 133 and a conductivity electrode TetraCon 96. Oxygen was fixed to be titrated by the Winkler method in the evening. For measurement of suspended matter, 2.51 of the Alchichica samples (1.5 1 for Atexcac) were filtered during the sampling on the lake through pre- 
Fig. 1 a, b Google Earth satellite images of Lake Alchichica; the white narrow zone visible in $\mathbf{b}$ along the lake shore corresponds with emerged carbonate microbialites. c The lake panorama seen from the southwestern crater wall; notable are the whitish masses of the emerged carbonate microbialites. d Bathymetric map of the lake made in June 2007 by the authors using GPS and echo sounder traverses
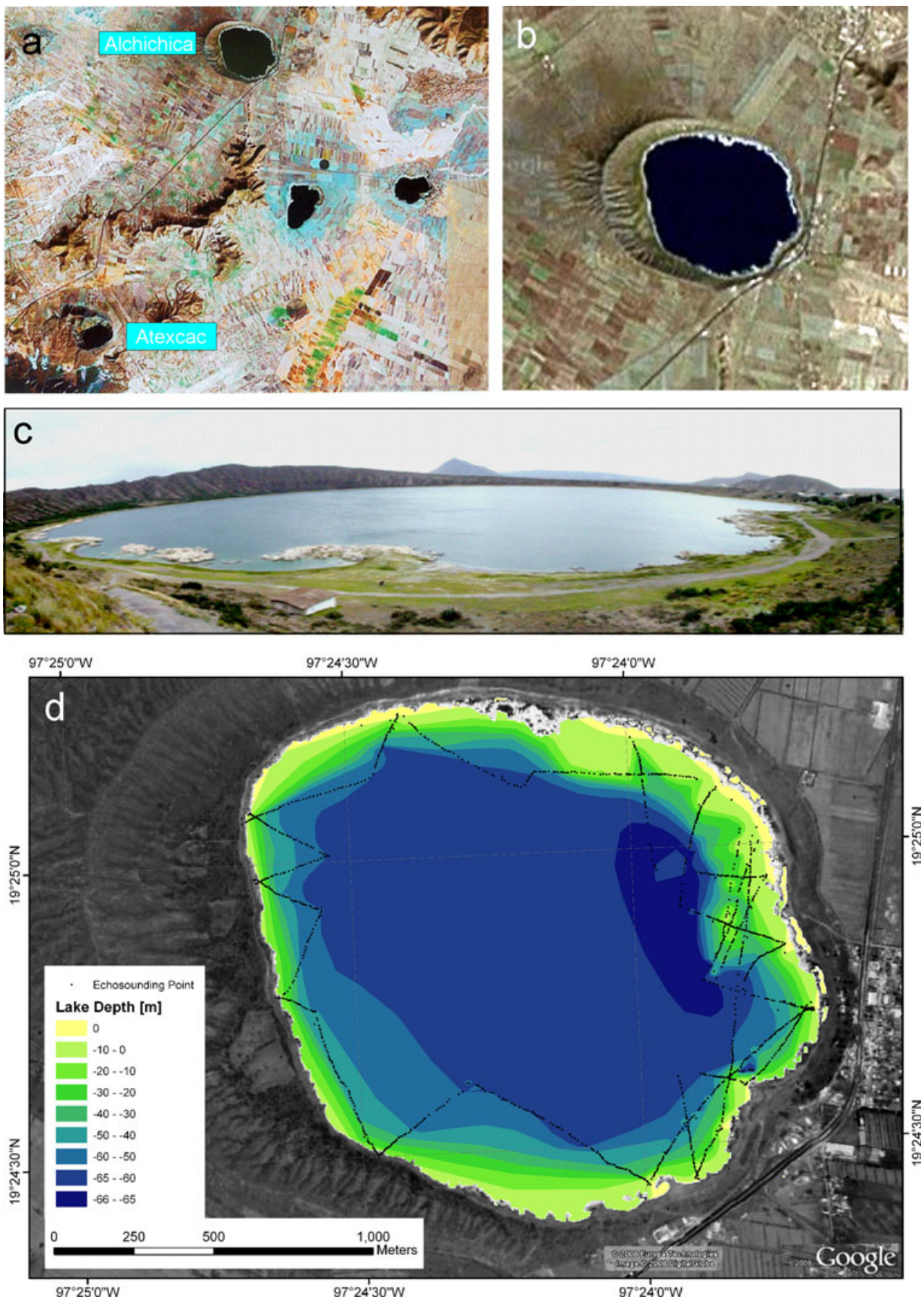

weighed, pre-combusted glass-fiber filters, and air-dried. In the laboratory, the filters were dried for 3 days at $55^{\circ} \mathrm{C}$ and re-weighed for measurements of suspended matter concentration.

In the laboratory of the Institute for Applied Geosciences at the Technische Universität Darmstadt, concentrations of cations and anions were measured by ion chromatography (Dionex ISS-90 with column CS12A for cations and Dionex DX-120 with column AS9HC for anions) and $\mathrm{Si}$ was determined by photometry (Silikat
Merck 14794). The ratio of the sum of cations to that of anions amounted to $1.0544 \pm 0.0082$, i.e., the concentration of the cations (including $\mathrm{Na}^{+}, \mathrm{K}^{+}, \mathrm{Mg}^{2+}, \mathrm{Ca}^{2+}, \mathrm{Li}^{+}$, and $\mathrm{NH}_{4}{ }^{+}$) is systematically higher by $5.44 \%$ than that of the anions (including $\mathrm{Alk}, \mathrm{Cl}^{-}, \mathrm{Br}^{-}, \mathrm{F}^{-}, \mathrm{SO}_{4}{ }^{2-}, \mathrm{PO}_{4}{ }^{3-}$, $\mathrm{NO}_{3}{ }^{-} \mathrm{NO}_{2}{ }^{-}$), an error typically associated with usage of different methods for anion and cation analysis.

The saturation indices of main carbonate minerals and of $\mathrm{PCO}_{2}$ were calculated with the computer program PHREEQE (Parkhurst et al. 1990). 

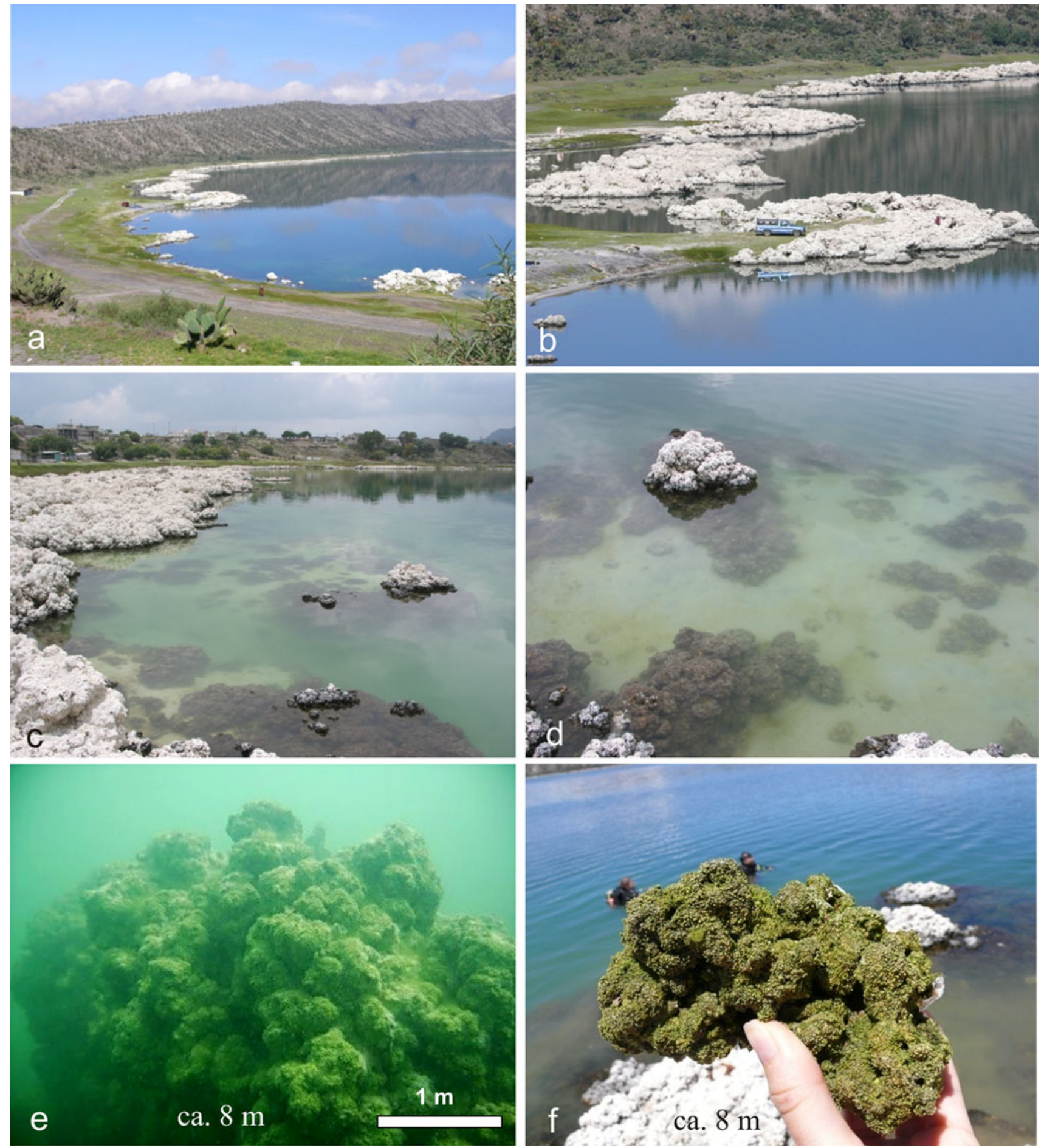

Fig. 2 a-d General views of masses of carbonate microbialites emerged above the present lake level; on $\mathbf{c}$ and $\mathbf{d}$ the darker, currently underwater growing (accreting) microbialites are visible. e Alchichica microbialites photographed at $8-\mathrm{m}$ water depth showing irregularly

nodular growth of the carbonates accreting by cyanobacterial mats (photo by F. Fernandez). f Sample of microbialite from the same water depth 
Table 1 Alchichica Crater Lake, areas and volumes, cumulative for 10 -m intervals

\begin{tabular}{lll}
\hline Depth $(\mathrm{m})$ & Area $\left(\mathrm{km}^{2}\right)$ & Volume $\left(\mathrm{m}^{3}\right)$ \\
\hline 0 & 2.257 & $1.05 \times 10^{8}$ \\
-10 & 1.969 & $8.43 \times 10^{7}$ \\
-20 & 1.839 & $6.52 \times 10^{7}$ \\
-30 & 1.721 & $4.74 \times 10^{7}$ \\
-40 & 1.600 & $3.08 \times 10^{7}$ \\
-50 & 1.443 & $1.55 \times 10^{7}$ \\
-60 & 1.099 & $2.48 \times 10^{6}$ \\
\hline
\end{tabular}
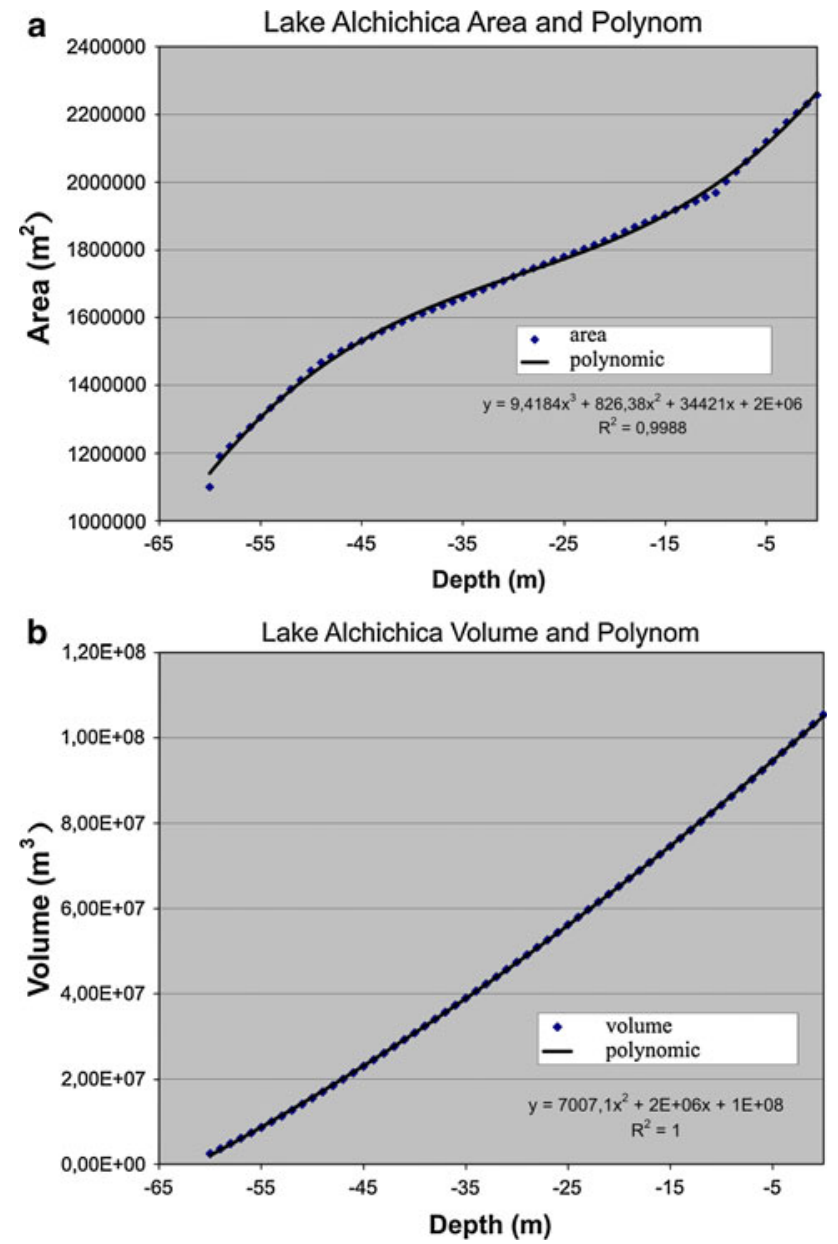

Fig. 3 Lake Alchichica: Graphs showing area-to-depth function (a), and volume-to-depth function (b)

Sampling for molecular microbiology studies, nucleic acid extraction, gene amplification, and construction of environmental gene libraries

Living microbialite fragments were collected by SCUBA diving along a depth gradient at a single station in the lake from immediately below the surface down to 14-m depth.
Samples for microbiology studies were taken with gloves and sterile forceps to minimize the risk of contamination. Subsamples were introduced in Falcon tubes and were fixed in situ in ethanol. They were kept at room temperature during transport and then stored at $4^{\circ} \mathrm{C}$ until processing. DNA was purified from approximately $300 \mu \mathrm{l}$ of ground stromatolites using the MoBio Power Soil ${ }^{\mathrm{TM}}$ DNA extraction kit (Carlsbad, CA, USA). This was done following the manufacturer's instructions. Duplicate DNA extractions from the same samples were done with the use of a modified classical phenol-chloroform extraction. For the latter, samples were subjected to six freezing/thawing cycles in liquid nitrogen to facilitate cell lysis. Subsequently, $80 \mu \mathrm{g} \mathrm{ml}^{-1}$ proteinase $\mathrm{K}, 1 \% \mathrm{SDS}, 1.4 \mathrm{M} \mathrm{NaCl}$, $0.2 \% \quad \beta$-mercaptoethanol and $2 \%$ hexadecyltrimethylammonium bromide (CTAB) (final concentrations) were added sequentially. Lysis suspensions were incubated overnight at $55^{\circ} \mathrm{C}$. Nucleic acids were extracted once with hot phenol $\left(65^{\circ} \mathrm{C}\right)$, once with phenol-chloroform-isoamylalcohol, and once with chloroform-isoamylalcohol, and were subsequently concentrated by ethanol precipitation and resuspended in $10 \mathrm{mM}$ Tris- $\mathrm{HCl}, \mathrm{pH} 8.5$. Small subunit rRNA genes were amplified from three selected samples (3, 6, and 8-m depths) by polymerase chain reaction (PCR) using a combination of the bacterialspecific primers B-27F (AGAGTTTGATCCTGGCTCAG) and 1492R (GGTTACCTTGTTACGACTT), and the cyanobacterial specific primers CYA106F (CGGACG GGTGAGTAACGCGTGA) and CYA1380R (TAACG ACTTCGGGCGTGACC). PCR reactions were performed under the following conditions: 35 cycles (denaturation at $94^{\circ} \mathrm{C}$ for $15 \mathrm{~s}$, annealing at $50-55^{\circ} \mathrm{C}$ for $30 \mathrm{~s}$, extension at $72^{\circ} \mathrm{C}$ for $2 \mathrm{~min}$ ) preceded by 2 -min denaturation at $94^{\circ} \mathrm{C}$, and followed by 7 -min extension at $72^{\circ} \mathrm{C}$. SSU rDNA clone libraries were constructed using the Topo TA Cloning System (Invitrogen) following the instructions provided by the manufacturers. After plating, positive transformants were screened by PCR amplification of inserts using flanking vector primers and PCR products partially sequenced using 1492R or CYA1380R (Cogenics, France). Sequences were deposited in GenBank with accession numbers HQ419013 to HQ419058.

Molecular phylogeny analyses

Only high-quality partial sequences (minimum length 700-800 bp) were retained for subsequent phylogenetic analyses. Partial sequences were compared to those in databases by BLAST (Altschul et al. 1997). A multiple alignment of cyanobacterial sequences was carried out using ClustalX (Thompson et al. 1994) and manually edited using the program ED from the MUST package (Philippe 1993). It contained 170 cyanobacteria representative 
of major groups retrieved from the curated Greengenes database (http://greengenes.lbl.gov/cgi-bin/nph-index.cgi), as well as our sequences and the closest relative sequences in GenBank (http://www.ncbi.nlm.nih.gov/). A preliminary distance (neighbor-joining) tree allowed the identification of 48 groups of highly similar sequences ( $>97 \%$ identity) or phylotypes. A selection of 98 representative cyanobacterial sequences was retained to construct a maximum likelihood tree (ML). The ML phylogenetic tree was reconstructed with TREEFINDER (Jobb et al. 2004) using 739 positions, applying a general time reversible model of sequence evolution (GTR), and taking among-site rate variation into account by using a six-category discrete approximation of a distribution. ML bootstrap proportions were inferred using 1,000 replicates.

Stable isotope analyses $\left(\delta^{13} \mathrm{C}\right.$ and $\left.\delta^{18} \mathrm{O}\right)$

Pulverized carbonate was extracted with a micro drill from rock samples. The samples were digested under vacuum with $100 \% \mathrm{H}_{3} \mathrm{PO}_{4}$ (ortho-phosphoric acid) for $24 \mathrm{~h}$ at $25^{\circ} \mathrm{C}$ (McCrea 1950). The released $\mathrm{CO}_{2}$, after freezing it out from the separation line, was analyzed on a Finnigan Mat delta plus gas mass-spectrometer in the Light Stable Isotopes Laboratory of the Institute of Geological Sciences and Institute of Paleobiology, Polish Academy of Sciences, Warsaw. The gas sample was introduced into the spectrometer in dual inlet mode. Measurements were repeated eight times and averages were calculated. The standard error of the spectrometer measurements was $0.02 \%$. Water samples $\left(\delta^{13} \mathrm{C}\right.$, DIC) were analyzed on a Finnigan Mat Delta E mass-spectrometer in the Laboratory of Isotope Geology and Geoecology, Department of Applied Geology and Geochemistry of the Institute of Geological Sciences, University of Wrocław.

The results are given in per mil deviation from the Vienna Pee Dee Belemnite (VPDB) standard using $\delta$ (delta) notation. The precision (reproducibility of replicate analyses) of both carbon and oxygen isotope analysis was usually better than $\pm 0.1 \%$. Data are normalized to the VPDB scale using National Bureau of Standards NBS-19 $\left(\delta^{18} \mathrm{O}=-2.20 \%\right.$ and $\delta^{13} \mathrm{C}=1.95 \%$ )

Microscopic (optical and SEM), EDS, and XRD analyses

The Alchichica microbialites were investigated on macroscopic slabs and in petrographic thin-sections under Zeiss Opton optical microscope. Scanning electron microscopy (SEM) at $25-\mathrm{kV}$ was used for examining samples of airdried mat surfaces sputtered with a 10-15-nm-thick layer of platinum or carbon. SEM examinations and EDS analyses were performed using a Philips XL-20 scanning microscope equipped with EDS detector ECON 6, system
EDX-DX4i and BSE detector for Compo or Topo detection (FEI product). XRD analyses of capillary carbonate microsamples were performed using a CGR-INEL diffractometer equipped with a cobalt lamp and focusing goniometer with transmission optics for Debey-Scherrer powder preparations.

\section{Lake Alchichica: existing data}

\section{Climate}

The air temperature fluctuates seasonally from -5.5 to $30^{\circ} \mathrm{C}$, with an annual mean of $14.4^{\circ} \mathrm{C}$. This high-altitude plateau (named Los Llanos de San Juan) has an annual precipitation regime of less than $400 \mathrm{~mm}$, and an annual evaporation rate of 500-600 mm, and can be defined as a "cold desert". The lake is supplied with precipitation and groundwater, which infiltrates from high mountains that encircle the lake basin from the east. Since these mountains are partly composed of calcareous Cretaceous deposits, the groundwaters infiltrating lake Alchichica are enriched in $\mathrm{Ca}^{2+}$ and $\mathrm{HCO}_{3}{ }^{-}$(Ramirez-Garcia and Vazquez-Gutierrez 1989; Vilaclara et al. 1993; Alcocer and Hammer 1998; Caballero et al. 2003).

\section{Microbialites}

Information on the occurrence of cyanobacterial microbialitic structures in Alchichica has been published by Tavera and Komárek (1996), who also included the basic hydrochemical and hydrographical data of Alchichica. Caballero et al. (2003) reported that until 1979, the lake had a much higher level, and that the white carbonate build-ups now visible as a ring around the lake (Fig. 1a-c) could not be seen. The lowering of the level by ca. 3-5 m was most probably caused by extraction of ground water for irrigation in the surrounding area. These microbial build-ups in the lake occur, according to Ramirez-Garcia and Novelo (1984) and Vilaclara et al. (1993), down to a depth of $12 \mathrm{~m}$, thus making sampling recent microbialites possible by SCUBA diving. The water transparency, measured with Secchi disc, is relatively high $\left(\mathrm{Z}_{\mathrm{SD}}=3.6-8 \mathrm{~m}\right.$ ) (our data and Arredondo et al. 1984; Ramirez-Garcia and VazquezGutierrez 1989). However, during short periods of blooms of the cyanobacterium Nodularia spumigena, this value falls dramatically (lowest in April, highest during wintersee Arredondo 1995).

\section{Thermal structure}

Arredondo et al. (1984) classified Alchichica as a polymictic lake with periodically repeated mixing and thermal 
discontinuities, with the exception of winter time when the lake is fully mixed (i.e., homothermal). However, Arredondo (1995) explains that the lake is "slightly" stratified during most of the year, except in winter. Summer temperature differences between surface and bottom reach $4.8^{\circ} \mathrm{C}$, whereas during winter-mixing it amounts to only about $1{ }^{\circ} \mathrm{C}$. In the opinion of Alcocer and Hammer (1998) and Alcocer et al. (2000), however, these data suggest monomixis rather than polymixis.

\section{Oxygen concentration}

The epilimnion has the highest dissolved oxygen (DO) values in summer $\left(7-7.5 \mathrm{mg} \mathrm{l}^{-1}\right)$. Towards the end of summer, DO amounts only to $5.8 \mathrm{mg}^{-1}$ in the lower epilimnion while below $20 \mathrm{~m}$ of depth DO is low $(<50 \%)$ or absent. Anoxic conditions were recorded in autumn below $30 \mathrm{~m}$ of depth. During winter-mixing the hypolimnion is replenished with DO (Arredondo 1995; Arredondo et al. 1984). The DO concentrations in the littoral zone can be higher than in the lake center, ranging from 6.9 to $8.1 \mathrm{mg} \mathrm{l}^{-1}$ (Alcocer et al. 1993a, b; Lugo et al. 1993).

\section{Chemistry}

The literature presents different concentrations of total dissolved solutes (TDS) (8.3 $\mathrm{g} \mathrm{l}^{-1}$, Taylor 1943; salinity, $8.2 \mathrm{~g} \mathrm{l}^{-1}$, Alvarez 1950; $7.1 \mathrm{~g} \mathrm{l}^{-1}$, Arrendondo et al. 1984; $8.5 \mathrm{~g} \mathrm{l}^{-1}$, Vilaclara et al. 1993). Our water column average was $8.7 \mathrm{~g} \mathrm{l}^{-1}$ (see below). Values measured in the littoral are slightly lower because of groundwater inflow (e.g., Alcocer et al. 1993a). Therefore, the lake can be classified as brackish.

In the system of salty and alkaline lakes, Lake Alchichica is classified as a typical soda lake (Hammer 1986;
Alcocer and Hammer 1998). $\mathrm{NaCl}$ and $\mathrm{Na}_{2} \mathrm{CO}_{3}$ are the main evaporation products of such lakes. The hydrochemistry of Alchichica is typically alkaline, dominated by sodium, magnesium, chloride, and bicarbonate ions. Published $\mathrm{pH}$ values (our average is 8.87 , see below) differ considerably in the literature: $9.0 \pm 0.1$ were reported by Ramirez-Garcia and Novelo 1984; Ramirez-Garcia and Vazquez-Gutierrez 1989; Vilaclara et al. 1993; and 10.2 by Alvarez 1950.

Although crater lakes are usually rich in silica because of their volcanic basement, its concentration in Alchichica is low $(0.01 \pm 0.07 \mathrm{mM})$. An interesting aspect of the lake's hydrochemistry is the relatively high level of boron, which, according to Ceballos et al. (1994), amounts to $3.79 \pm 0.83 \mathrm{mM}$. An extensive compilation of hydrochemical data (mean annual values for 10 years) for the volcanic lakes of the El Secco valley was published by Ramirez-Garcia and Novelo (1984) and Vilaclara et al. (1993).

\section{Lake Alchichica: new data}

Hydrophysics and geochemistry

The results of the main cations and anions for the water column profile do not show any variation in concentration beyond analytical scatter. They are therefore reported here as means of all eight samples (Table 2).

Table 3 gives the main ion concentration for the seepage water and the Lake Atexcac sample (due to time constrains it was not possible to measure alkalinity in the field, it is here calculated by cation-anion balance, i.e., as carbonate alkalinity).

Table 2 Concentrations of main anions and cations of Alchichica Lake, means and standard deviations of eight water column samples

\begin{tabular}{|c|c|c|c|c|}
\hline $\mathrm{Cl}^{-}\left(\right.$meq $\left.1^{-1}\right)$ & Alk (meq $1^{-1}$ ) & $\mathrm{SO}_{4}^{2-}\left(\mathrm{meq} \mathrm{1} 1^{-1}\right)$ & $\mathrm{Br}^{-}\left(\right.$meq $\left.1^{-1}\right)$ & $\mathrm{F}^{-}\left(\right.$meq $\left.1^{-1}\right)$ \\
\hline $87.3 \pm 0.75$ & $30.9 \pm 0.35$ & $16.73 \pm 0.15$ & $0.10 \pm 0.004$ & $0.008 \pm 0.003$ \\
\hline $\mathrm{Na}^{+}\left(\right.$meq $\left.1^{-1}\right)$ & $\mathrm{Mg}^{2+}\left(\right.$ meq $\left.1^{-1}\right)$ & $\mathrm{K}^{+}\left(\right.$meq $\left.1^{-1}\right)$ & $\mathrm{Ca}^{2+}\left(\right.$ meq $\left.1^{-1}\right)$ & $\mathrm{Li}^{+}\left(\right.$meq $\left.1^{-1}\right)$ \\
\hline $100.5 \pm 0.74$ & $35.61 \pm 0.49$ & $5.32 \pm 0.16$ & $0.735 \pm 0.17$ & $0.26 \pm 0.098$ \\
\hline
\end{tabular}

Table 3 Concentrations of main anions and cations of Alchichica Lake seepage water and Atexcac Lake surface water

\begin{tabular}{|c|c|c|c|c|c|}
\hline Sample & $\mathrm{Cl}^{-}\left(\right.$meq $\left.1^{-1}\right)$ & Alk (meq $1^{-1}$ ) & $\mathrm{SO}_{4}{ }^{2-}\left(\right.$ meq $\left.1^{-1}\right)$ & $\mathrm{Br}^{-}\left(\right.$meq $\left.1^{-1}\right)$ & $\mathrm{F}^{-}\left(\right.$meq $\left.1^{-1}\right)$ \\
\hline Al 9 seepage & 5.47 & 9.34 & 3.07 & 0.01 & 0.03 \\
\hline \multirow[t]{2}{*}{ Atexcac } & 96.60 & 28.30 & 3.53 & 0.12 & 0.06 \\
\hline & $\mathrm{Na}^{+}\left(\right.$meq $\left.1^{-1}\right)$ & $\mathrm{Mg}^{2+}\left(\right.$ meq $\left.\mathrm{l}^{-1}\right)$ & $\mathrm{K}^{+}\left(\right.$meq $\left.1^{-1}\right)$ & $\mathrm{Ca}^{2+}\left(\right.$ meq $\left.1^{-1}\right)$ & $\mathrm{Li}^{+}\left(\right.$meq $\left.1^{-1}\right)$ \\
\hline Al 9 seepage & 6.84 & 7.48 & 0.26 & 3.34 & 0.006 \\
\hline Atexcac & 77.00 & 46.20 & 2.34 & 2.14 & 0.669 \\
\hline
\end{tabular}


Table 4 Hydrophysical data and oxygen and nutrient concentrations of all measured samples ( $n . d$. not determined; $0=$ below detection limit of the method)

\begin{tabular}{|c|c|c|c|c|c|c|c|c|c|c|c|c|c|}
\hline Sample & $\begin{array}{l}\text { Depth } \\
\text { (m) }\end{array}$ & $\begin{array}{l}\text { Temp } \\
\left({ }^{\circ} \mathrm{C}\right)\end{array}$ & $\mathrm{pH}$ & $\begin{array}{l}\text { Cond. } \\
\left(\mathrm{mS} \mathrm{cm}^{-1}\right)\end{array}$ & $\begin{array}{l}\mathrm{SM} \\
\left(\mathrm{mg}^{-1}\right)\end{array}$ & $\begin{array}{l}\text { TDS } \\
\left(\mathrm{mg} \mathrm{l}^{-1}\right)\end{array}$ & $\begin{array}{l}\mathrm{O}_{2} \\
\left(\mu \mathrm{mol} 1^{-1}\right)\end{array}$ & $\begin{array}{l}\mathrm{Si} \\
\left(\mu \mathrm{mol} 1^{-1}\right)\end{array}$ & $\begin{array}{l}\mathrm{NO}_{2}^{-} \\
\left(\mu \mathrm{mol} 1^{-1}\right)\end{array}$ & $\begin{array}{l}\mathrm{NO}_{3}^{-} \\
\left(\mu \mathrm{mol}^{-1}\right)\end{array}$ & $\begin{array}{l}\mathrm{PO}_{4}^{3-} \\
\left(\mu \mathrm{mol} 1^{-1}\right)\end{array}$ & $\begin{array}{l}\mathrm{NH}_{4}^{+} \\
\left(\mu \mathrm{mol}^{-1}\right)\end{array}$ & $\mathrm{N} / \mathrm{P}$ \\
\hline Al 1 & 0 & 19.8 & 8.89 & 13.39 & 2.0 & 8853 & 203 & 17.1 & 0.22 & 3.71 & 0.63 & 0 & 6.23 \\
\hline $\mathrm{Al} 2$ & 10 & 18.3 & 8.89 & 13.28 & 2.6 & 8828 & 213 & 5.3 & 0.65 & 0.97 & 1.58 & 0 & 1.03 \\
\hline Al 3 & 20 & 15.3 & 8.89 & 13.28 & 2.8 & 8782 & 97 & 5.0 & 1.74 & 3.23 & 0.00 & 0 & n.d. \\
\hline $\mathrm{Al} 4$ & 26 & 14.8 & 8.88 & 13.38 & 3.2 & 8766 & 41 & 3.6 & 1.74 & 5.00 & 0.53 & 0 & 12.71 \\
\hline Al 5 & 30 & 14.6 & 8.88 & 13.36 & 3.0 & 8637 & 41 & 10.7 & 1.09 & 14.68 & 1.79 & 0 & 8.81 \\
\hline Al 6 & 40 & 14.1 & 8.88 & 13.37 & 1.8 & 8784 & 16 & 20.3 & 0.00 & 10.48 & 1.05 & 0 & 9.98 \\
\hline Al 7 & 50 & 14.0 & 8.87 & 13.37 & 3.8 & 8733 & 6 & 29.3 & 0.00 & 3.39 & 3.05 & 5.7 & 2.99 \\
\hline Al 8 & 60 & 13.8 & 8.87 & 13.37 & 1.9 & 8720 & 22 & 51.6 & 0.00 & 7.10 & 5.16 & 15 & 4.28 \\
\hline $\begin{array}{l}\text { Al } 9 \text { - } \\
\text { seepage }\end{array}$ & 0 & 25.4 & 7.30 & 2.1 & n.d. & 668 & n.d. & 694.3 & 0.22 & 0.16 & 0.53 & 0 & 0.71 \\
\hline Atexcac & 0 & 23.1 & 8.22 & 11.7 & 6.9 & 6086 & n.d. & 950.7 & 1.74 & 43.22 & 4.42 & 291 & 76.0 \\
\hline
\end{tabular}

$\mathrm{NO}_{2}$ and $\mathrm{NH}_{4}$ data of Alchichica water column are those measured in the field, while the seepage water and Atexcac samples were measured by IC in the lab. $\mathrm{PO}_{4}$ and $\mathrm{NO}_{3}$ data were measured by IC. $S M$ Suspended matter

Hydrophysical data and oxygen and nutrient concentrations vary noticeable with depth. These values are given in Table 4. The profiles are plotted in Fig. 4b, c.

The hydrochemical data were used to calculate carbonate, phosphate, and $\mathrm{SiO}_{2}$ mineral saturation indices and $\mathrm{CO}_{2}$-pressure $\left(\mathrm{PCO}_{2}\right)$ with PHREEQC (Table 5) and with the WATEQ4F constants (Table 6) (Parkhurst et al. 1990). The saturation index (SI) is defined as the decadic logarithm of the quotient of the ion activity product and the mass balance constant, for example (for calcite):

$\mathrm{SI}_{\text {calcite }}=\log \left(\left[\mathrm{Ca}^{2+}\right] *\left[\mathrm{CO}_{3}^{-2}\right] / \mathrm{K}_{\text {Calcite }}\right)$

Thus, positive values denote supersaturation, zero is saturation, and negative values represent undersaturation with regard to the respective mineral.

\section{Discussion of hydrochemistry}

Alchichica and Atexcac are crater lakes without any surface water tributaries and without any surface outlets. Their water balance is determined by precipitation and evaporation. In addition, they receive groundwater seeping out of the porous tephra of their respective volcanic edifices and they may lose lake water into the deeper ground water body; thus, they are essentially groundwater outcrops. Their water levels are altered by climatic variation and (potentially) by groundwater extraction. In the case of Alchichica, a terrace surrounds the present lake, which indicates that the ground water level used to be higher. This once higher level correlates with the water body that was responsible for precipitating the stromatolites that ring the present lake. Thus, the hydrochemical conditions of the present lake must not necessarily reflect the conditions that caused the growth of the exposed stromatolite generations. Nevertheless, the study of the present lake will give us clues about the nature of the former lake.

The two lakes sampled are both brackish (i.e., $>5,000 \mathrm{mg} / \mathrm{l})$ in salinity: for Alchichica the sum of the total dissolved solids (TDS) amounts to $8,763 \pm 67.6 \mathrm{mg} \mathrm{l}^{-1}$, for Atexcac it is $6,086 \mathrm{mg} / \mathrm{l}$. On the contrary, the seepage water sample amounted to only $668 \mathrm{mg} \mathrm{l}^{-1}$. Thus, the groundwater that contributes to the lakes is less mineralized, and evaporation must be the mechanism, that increases TDS in the lake. The factor of enrichment for Alchichica Lake is 13 (i.e., 8,763/668), at least with respect to the one seepage sample available.

When we sampled the lake in June 2007, the lake was well mixed with respect to its main ions. However, seasonal heating had established a warmer, ca. 15 -m-thick surface layer (Table 4) above a cooler (about $14^{\circ} \mathrm{C}$ ) bottom layer. The amount of TDS listed in Table 4 suggests that the ion concentration decreases with increasing depth, and that the difference amounts to about $1.5 \%$ of total TDS. This small difference is, however, within analytical scatter and may not be significant. Should it be significant, then density decrease caused by the concentration decrease is counterbalanced by the higher temperature in the surface layer causing a density increase downwards. The conductivity measurements are also inconclusive, and do not show a clear trend. In any case, we must conclude that water column stability in the lake is low, and that the lake must have mixed during the cooler time of the year prior to sampling.

Main ion concentrations of the lakes and of the seepage water are compared in Table 4. They reveal the main differences between the lakes and the seepage water. In Alchichica 
Fig. 4 a Comparison of the major ions of the three water bodies (mean of eight

Alchichica water column samples), Alchichica seepage water, and the neighbor crater lake Atexcac (see Fig. 1a). b, c Vertical profiles of oxygen, silicon, and ammonium concentrations (b), and of nitrite, nitrate and phosphate (c)
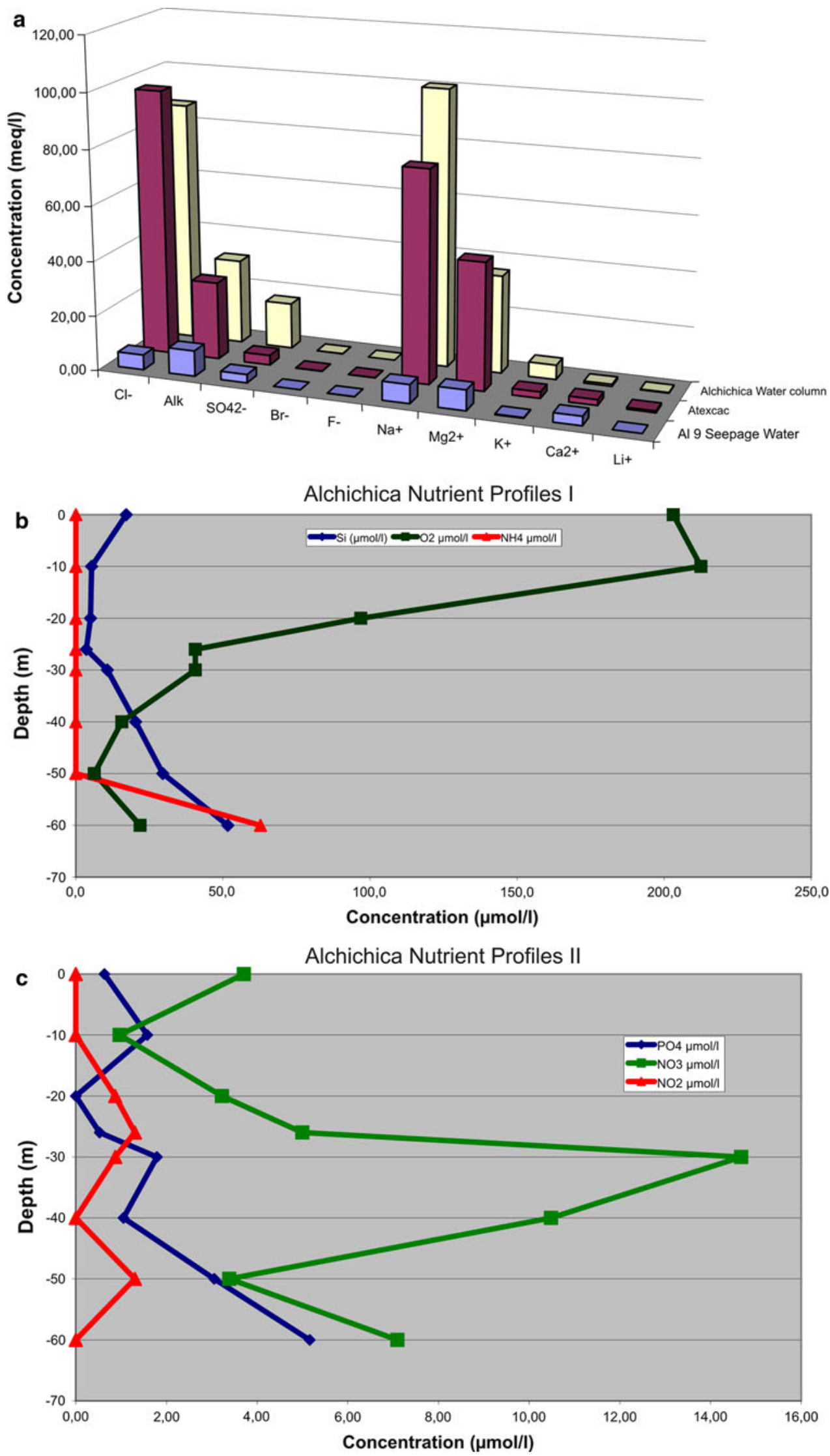
Table 5 Means and standard deviation of saturation indices and $\mathrm{CO}_{2}$-pressure in ppmv for water column samples of Alchichica crater lake

\begin{tabular}{lllll}
\hline SI calcite & SI aragonite & SI dolomite & SI OH-apatite & $P C O_{2}(\mathrm{ppmv})$ \\
\hline $1.058 \pm 0.13$ & $0.907 \pm 0.126$ & $3.859 \pm 0.180$ & $-2.97 \pm 1.25$ & $1265 \pm 32.1$ \\
\hline
\end{tabular}

The saturation index $(S I)$ is defined as $\log \left(\right.$ ion activity product $\left./ \mathrm{K}_{\text {mineral }}\right)$

Table 6 Saturation indices of various carbonate minerals and of $\mathrm{SiO}_{2}$ species of Alchichica seepage water, Alchichica averaged water column composition, and Atexcac Lake water sample

\begin{tabular}{|c|c|c|c|c|c|c|c|}
\hline Sample & SI calcite & SI aragonite & SI dolomite & SI huntite & SI hydromagnesite & SI magnesite & SI nesquehonite \\
\hline Seepage & 0.19 & 0.05 & 0.80 & -2.34 & -11.66 & 0.04 & -2.36 \\
\hline Alchichica & 1.05 & 0.90 & 3.90 & 5.22 & 0.68 & 2.28 & -0.13 \\
\hline \multirow[t]{2}{*}{ Atexcac } & 1.05 & 0.91 & 3.53 & 4.12 & -1.76 & 1.91 & -0.50 \\
\hline & SI quartz & SI silicagel & SI cristobalite & SI chalcedony & SI OH-apatite & SI F-apatite & $\mathrm{PCO}_{2}$ (ppmv) \\
\hline Seepage & 0.90 & -0.08 & 0.50 & 0.46 & -4.04 & -1.58 & 24.000 \\
\hline Alchichica & -0.73 & -1.71 & -1.13 & -1.18 & & & 1.600 \\
\hline Atexcac & 1.05 & 0.06 & 0.65 & 0.60 & -0.77 & 0.90 & 6.600 \\
\hline
\end{tabular}

$\mathrm{PCO}_{2}\left(\mathrm{CO}_{2}\right.$ partial pressure). Water column hydroxyl-apatite SI was not calculated because of the large variability of $\mathrm{PO}_{4}$ concentration

samples, we find $\mathrm{Na}>\mathrm{Cl}$, while for Atexcac $\mathrm{Na}<\mathrm{Cl}$. In Atexcac, $\mathrm{Mg}$ is of a higher significance, but sulphate is less abundant than in Alchichica. Alkalinity is comparable in both lakes, but in the seepage water it is the most important anion. $\mathrm{Mg}$ is the most important cation in the seepage water, while $\mathrm{Ca}$ is the only ion that is indisputably higher in the seepage water compared to the lake water bodies. The water of Atexcac has a composition of $\mathrm{Cl} \gg \mathrm{Alk} \gg \mathrm{SO}_{4}$ and $\mathrm{Na}>\mathrm{Mg} \gg$ $\mathrm{K}>\mathrm{Ca}$, and that of Alchichica $\mathrm{Cl} \gg \mathrm{Alk}>\mathrm{SO}_{4}$ and $\mathrm{Na} \gg \mathrm{Mg} \gg \mathrm{K} \gg \mathrm{Ca}$ while the seepage water is characterized by $\mathrm{Alk}>\mathrm{Cl}>\mathrm{SO}_{4}$ and $\mathrm{Mg}>\mathrm{Na}>\mathrm{Ca} \gg \mathrm{K}$. These main ion results compare well with those published by Armienta et al. (2008) who analyzed four water samples: two from Lake Alchichica ( $0 \mathrm{~m}$ and $61 \mathrm{~m}$ depth) and two from Lake Atexcac (0 and $31 \mathrm{~m}$ depth).

The high Mg-concentration in the seepage sample is the result of the weathering of $\mathrm{Mg}$-rich silicates in the percolated volcanic tephra. Similarly, high concentrations of $\mathrm{Ca}$ are mobilized. Both $\mathrm{Ca}$ and $\mathrm{Mg}$ are nearly balanced by alkalinity $(\mathrm{Mg}+\mathrm{Ca}) / \mathrm{Alk}=1.16 \quad$ (with the reminder probably balanced by sulphate from sulphuric acid weathering). In Alchichica, the ratio is similar, i.e., 1.18, in spite of the fact that the $\mathrm{Mg} / \mathrm{Ca}$ molar ratio increases from 2.24 in the seepage water to 48.4 in the lake. Thus, we conclude that $\mathrm{Ca}$ is preferentially removed, while $\mathrm{Mg}$ largely remains and is accumulated. Also, the high alkalinity of 30.9 meq $1^{-1}$ caused the lake to have a high $\mathrm{pH}$ (8.87 on average), which makes it a soda lake (compare Kempe and Kazmierczak 2011).

The calculation of mineral saturation indices for Alchichica (Table 5,6) shows that the saturation with respect to the carbonate minerals in the lake is exceeded by far. For calcite and aragonite, the saturation is about tenfold higher than equilibrium and a supersaturation needed to cause extracellular precipitation is present: similar values are observed in other stromatolite precipitating environments (compare Kempe et al. 1991; Kempe and Kazmierczak 1994; Kazmierczak and Kempe 2006; Reimer et al. 2009). Similarly, dolomite is supersaturated by almost 10,000 times, a value comparable to other sites, such as highly alkaline Lake Van (Reimer et al. 2009).

SI calculation for the seepage water (Table 6) shows that it is near saturation with respect to calcite, aragonite, and magnesite, illustrating that there had been a sufficient length of time for the water to come into equilibrium with these minerals, and that a further increase in concentrations of $\mathrm{Ca}$ and $\mathrm{Mg}$ cannot be expected by longer percolation times. This saturation was reached under high $\mathrm{PCO}_{2}$ conditions $(24,000 \mathrm{ppmv})$, illustrating the importance of the $\mathrm{PCO}_{2}$ for mobilizing $\mathrm{Ca}$ and $\mathrm{Mg}$ through silicate weathering. It is also interesting to note that the seepage water is not saturated with regard to huntite $\left(\mathrm{CaMg}_{3}\left(\mathrm{CO}_{3}\right)_{4}\right)$ and hydromagnesite $\left(\mathrm{Mg}_{5}\left(\mathrm{CO}_{3}\right)_{4}(\mathrm{OH})_{2}+4 \mathrm{H}_{2} \mathrm{O}\right)$, while the lake water is highly supersaturated with respect to these two minerals, a finding in accordance with the fact that these minerals precipitate in the lake (see below). Nesquehonite $\left(\mathrm{MgCO}_{3}+3 \mathrm{H}_{2} \mathrm{O}\right)$ is, on the other hand, not saturated in any of the samples. Lake Atexcac, similar in its saturation with regard to calcite, aragonite, dolomite and magnesite to Lake Alchichica, shows, however, a much lower huntite supersaturation (by over a factor of ten) and a hydromagnesite undersaturation. 
The variation of the saturation in the Alchichica system with regard to the $\mathrm{SiO}_{2}$ mineral species is opposite to that of the carbonate minerals: it is above or near saturation in the seepage water but below saturation in the lake. This illustrates that in the lake diatoms effectively extract silica from the lake, while in the seepage water weathering has reached equilibrium. Silica extraction in Lake Atexcac does not seem to be effective. Possibly, the diatom bloom had not yet started there or is inhibited by other factors.

Figure 4 shows that oxygen is much depleted already at depth, with ammonium evolving near the bottom. Silica, phosphate, and nitrate are also depleted in the surface layers and enriched toward the deeper water layers. Nitrate shows a pronounced maximum at $30-\mathrm{m}$ depth, which may be the relict of the complete mixing and oxidation of the lake. The reduction of nitrate above its $30-\mathrm{m}$ peak produced a maximum in nitrite (20 and $26 \mathrm{~m}$ ) while towards the bottom reduction seems to directly produce ammonium. Due to the oxygen depletion with depth, denitrification seems to be an important process in the lake explaining the highly variable $\mathrm{N} / \mathrm{P}$ ratio $\left(\left[\mathrm{NO}_{2}{ }^{-}+\mathrm{NO}_{3}{ }^{-}+\mathrm{NH}_{4}{ }^{+}\right] /\right.$ $\mathrm{PO}_{4}{ }^{3-}$; Table 4). Apart from the 26-m sample (where phosphate seems to be at a minimum due to photosynthesis) all samples have an N/P molar ratio of below the Redfield N/P of 12. Sufficient amounts of phosphate found in the seepage water (Table 4) and in the lake show that phosphate is not a limiting factor for biological production and that it is replenished through weathering. Phosphate is removed from the lake by deposition of organics, because the low Ca-concentration keeps the hydroxyl-apatite below saturation at all depths. Hydroxyl-apatite is not supersaturated in any of the samples (average in the water column $-2.97 \pm 1.25$; Table 5). Thus, it does not regulate phosphate concentration. This role may be played by fluor-apatite that is supersaturated in Atexcac (Table 6).

The intensive weathering activity within the volcanic suite is also illustrated by the high silica concentration of almost $700 \mu \mathrm{mol} \mathrm{l}^{-1}$ in the seepage water (Table 4). Compared to the silica content of the water column, the lake must act as a sink for silica. This conclusion is in accordance with the observation that the stromatolites are highly silicified.

Visibility depth in Lake Alchichica during our sampling (June 2007) was $3.65 \mathrm{~m}$ (measured by Secchi disc), and the surface water layer looked murky, suggesting an abundance of phytoplankton in the euphotic zone. This is in accordance with the fact that enough nutrients were still available at this time of the year in the upper layers of the lake. Total stock of plankton was between 1.8 and $3.8 \mathrm{mg} / \mathrm{l}^{-1}$, a relatively low value (Table 4, SM). This suggests that much of the plankton was composed of very small species, potentially mostly cyanobacteria (Nodularia spumigena-see Arrendondo et al. 1984).
In spite of the pronounced oxygen depletion with depth (Table 4), the $\mathrm{PCO}_{2}$ does not show a corresponding variation and stays rather stable at 1,265 \pm 32.1 ppmv (Table 5) throughout the water column. This is probably due to the buffering of the carbonate system. The relatively high value (four times the atmospheric value) shows that the lake is most probably still exposed to volcanic degassing. In order to clarify this, isotope studies would be needed.

\section{Alchichica biota}

Phytoplankton

Arredondo et al. (1984) identified 23 phytoplankton genera in Alchichica: 14 Chrysophyta, five Cyanophyta (Cyanobacteria), and four Chlorophyta. The most common at that time were: Chrysophyta-Chaetocerus similis (90.2\%) of all taxa), Stephanodiscus niagarae, Coscinodiscus sp. and Cyclotella striata; Cyanophyta-Nodularia spumigena (7.4\%-blooms); Chlorophyta (2.4\%)_Cosmarium. Other algae, identified to have frequent presence by Garzón (1990), are: Eutetramorus fottii, Oocystis, and Cyclostephanus dubius.

\section{Zooplankton}

Lugo et al. (1993) studied littoral communities of Protozoa and identified 44 species, from which, using the classification of those authors, 17 represented Flagellata, 17 Ciliata, and ten Sarcodina. The most abundant flagellate was Bodo caudatus, and the most common ciliate Cyclidium glaukoma. Based on these observations, the authors defined the trophic status of Alchichica as oligo-mesotrophic. Garzón (1990); Vilaclara et al. (1993), and Macek et al. (1994) derived the same classification, albeit based on the concentration of chlorophyll $a$.

\section{Benthic invertebrates}

Benthic communities of invertebrates were studied by Alcocer (1995) and Alcocer et al. (1993b; 1998). They identified 44 taxa, predominantly representing: Oligochaeta, Amphipoda, Chironomidae, and Hirudinae (together $99 \%$ of invertebrate biomass). Common species are: Limnodrilus hoffmeisteri (Tubificidae), Hyalella azteca (Amphipoda), and Tanypus (Apelopia) (Chironomidae). The last taxon is the most diversified (14 species).

\section{Vertebrates}

The fish Poblana alchichica (Atherinidae) described by Buen (1945) appears to be endemic for Alchichica. 
A curiosity is also the occurrence of an endemic neotenic salamander species described as Ambystoma subsalsum (Taylor 1943), which later was re-classified as Ambystoma taylori (Brandon et al. 1981; Flores-Vilella 1993).

Aquatic macrophytes

According to Ramirez-Garcia and Novelo (1984) and Ramirez-García and Vázquez-Gutiérrez (1989), two species of macrophytes have been identified in Alchichica, these are: Rupia maritima and Cyperus laevigatus.

Molecular characterization of the cyanobacterial diversity

The taxonomy of the microbialite-associated cyanobacteria was determined (in addition to the classical morphological method-see results by Tavera and Komárek (1996) and examples on Fig. 5) by molecular analyses based on the
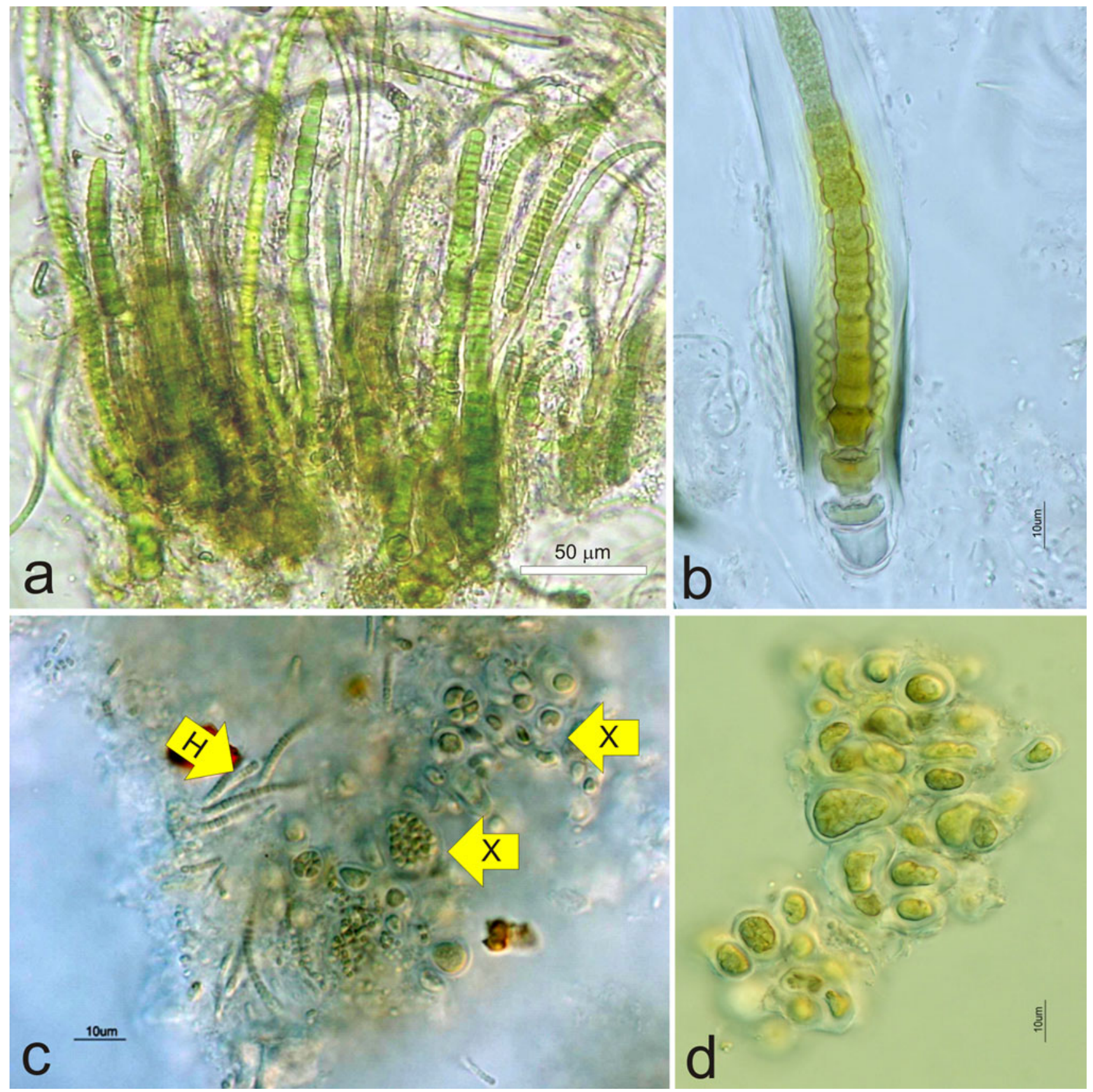

Fig. 5 Examples of characteristic phototrophic microorganisms composing the shallow water mats. a, b Rivularia sp. c Heteroleibleinia profunda (arrow H), Xenococcus candelariae (arrows X). d Ulvophycidae s.l. 
amplification, cloning, and sequencing of small-subunit ribosomal RNA (SSU rRNA) genes performed on samples collected during our 2007 Alchichica expedition. The molecular analysis of the cyanobacterial community associated with Alchichica microbialites gave results on the taxonomic diversity present in accordance with those from morphological studies.

The cyanobacteria associated to the Alchichica microbialites (as detected by molecular methods based on the amplification, cloning and sequencing of SSU rRNA genes) were highly diverse (Figs. 6 and 7). This diversity was present both at high taxonomic level, where members belonging to major order-level taxonomic groups were identified, but also within groups for a given high-rank taxon. We found members of the Chroococcales, Pleurocapsales, Nostocales, Oscillatoriales, Prochlorales, as well as members from the recently discovered group of Acaryochloris. The distribution of sequences belonging to the different cyanobacterial groups appeared to vary as a function of depth (Fig. 6), although local heterogeneity and local dominance of some species could also have an influence and may bias this observation. For instance, it is likely that the presence of filamentous cyanobacteria may dominate in SSU rRNA gene libraries because they contribute more biomass.

Microbialite samples from 3 to $4 \mathrm{~m}$ depth (AL66) contained cyanobacteria belonging to the filamentous Nostocales and Oscillatoriales and to the coccoid colonial Pleurocapsales (Fig. 7). Within the Nostocales, we detected a variety of phylotypes that were related to the genera Calothrix and Rivularia. They are characterized by filamentous trichomes that taper from the base towards the end of the filament and which form heterocysts specialized in

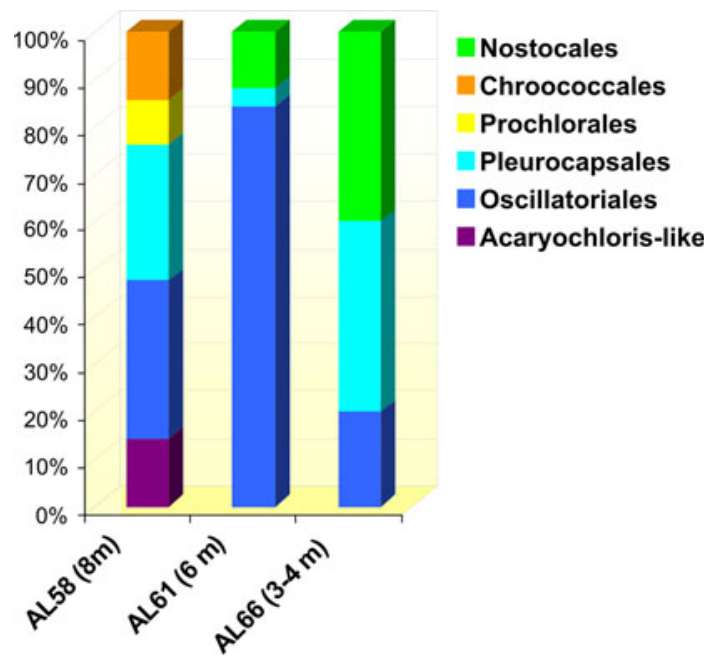

Fig. 6 Relative proportion of cyanobacterial SSU rRNA genes amplified from Alchichica cyanobacterial mats of different depths nitrogen fixation at the apical base of filaments. We also found three Oscillatoriales phylotypes, two of them related to the genus Leptolyngbya and a third phylotype (represented by the clone AL66-2CY-15) belonging to a diverse group of sequences that had no close relative within Oscillatoriales sequences in databases, though it appeared well represented also in deeper samples (Fig. 7). The Pleurocapsales, coccoid cyanobacteria whose characteristic colonies are embedded in mucilage, were fairly abundant in this sample and their sequences clustered in two major phylotypes, one related to the genus Pleurocapsa, and the other one related to environmental sequences retrieved from microbialites of the alkaline Lake Van, Turkey (López-García et al. 2005).

The SSU rRNA gene library of the microbialite sample from $6 \mathrm{~m}$ depth (AL61) was largely dominated by Oscillatoriales. Yet, as in the upper sample, Pleurocapsales and Nostocales were also identified, but in lower proportions (Fig. 6). The Pleurocapsales sequences from this sample belonged to a single phylotype, represented by clone AL58-2CY-17, which was also found in the two other depths and whose closest relatives in GenBank with $97 \%$ identity at the SSU rRNA locus were, again, cyanobacterial sequences from Lake Van microbialites (Fig. 6). This suggests that this is a group of Pleurocapsales cyanobacteria typically adapted to microbialites of alkaline lakes. However, described species or sequences for described species of this group are not available yet. In addition, a single sequence of a cyanobacterium of uncertain ascription that appeared to branch at the base of the Pleurocapsales (AL61-2CY-2) was identified, although the position of this sequence is not statistically supported. Its closest relatives, though only $92 \%$ identical at the SSU rRNA gene sequence level, belonged to the LPP group, a lineage of cyanobacteria deposited as Oscillatoriales in the Japanese MCBI collection (http://www.mbio.jp/mbic). By far, the most relatively abundant cyanobacterial group at this depth corresponded to the Oscillatoriales. They were not only abundant, but also quite diverse, encompassing 15 different phylotypes (Fig. 7). Some of these were related to the genera Leptolyngbya and Halomicronema, but most of them did not have close relatives among the described species for which sequences are available in the database. In addition to cyanobacterial sequences, we also amplified SSU rDNA sequences from diatom chloroplasts, indicating the presence of diatoms at this depth.

The deepest microbialite sample analyzed in this study, AL58 (8 $\mathrm{m}$ depth), was the one in which the largest highrank taxon diversity was found (Fig. 6). As in the two shallower samples, members of the Pleurocapsales and Oscillatoriales, which appeared relatively more abundant, were identified. By contrast, Nostococcales sequences were not detected. Instead, members of the coccoidal groups 


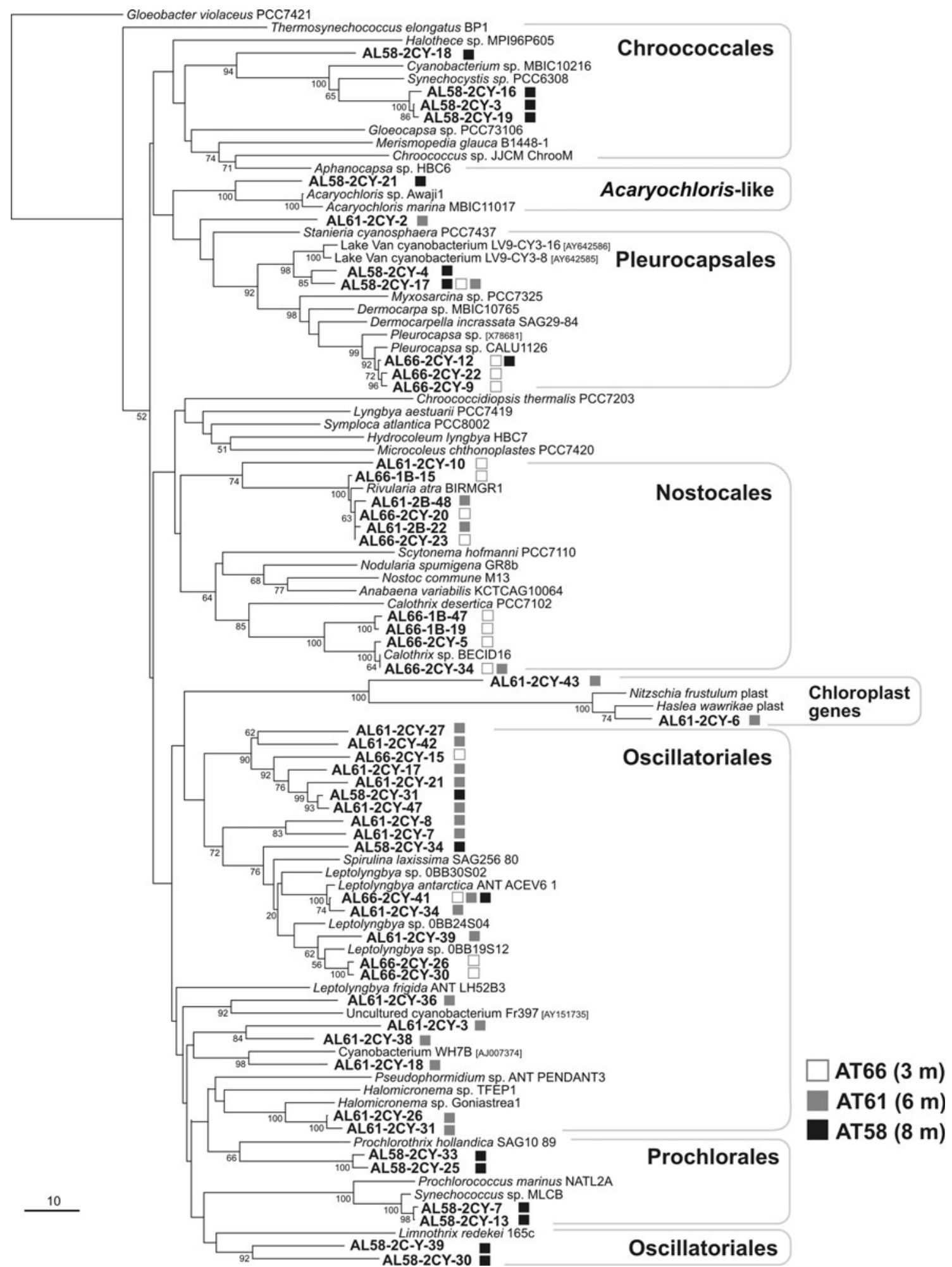

Fig. 7 Phylogenetic tree showing the position of cyanobacterial SSU rDNA sequences from Alchichica cyanobacterial mats. The tree was constructed by neighbor-joining using 739 unambiguously aligned positions. Bootstrap values were calculated from 1,000 replicates; only those above $50 \%$ are shown at nodes. Sequences from our Alchichica libraries are shown in bold. The depth at which a given phylotype was found is indicated by white, grey, or black squares 
Chroococcales and Prochlorales were identified, together with a sequence related to the chlorophyll $d$-containing Acaryochloris (Fig. 7). Although Acaryochloris members are coccoid cells of tiny sizes, their genome is among the largest sequenced among cyanobacteria (Swingley et al. 2008). The presence of chlorophyll $d$ in this cyanobacterium implies that it carries out photosynthesis efficiently near the far red, explaining its presence in niches where light intensity is low, such as underneath coral-reef ascidians (Kühl et al. 2005) and, more recently, in the Shark Bay stromatolites (Goh et al. 2009). This would also correlate with its presence in deeper samples from Alchichica, although a more thorough survey would be required to test this hypothesis.

As mentioned above, these molecular diversity data are consistent with optical microscopy observations of the same samples showing a wide diversity of filamentous, including Rivularia/Calothrix-like, cyanobacteria, together with a variety of cyanobacterial colonies surrounded by mucilage covers of different thickness. These data confirm and complete the morphological inspection and the classical taxonomy of the cyanobacteria associated with the Alchichica microbialites (see Tavera and Komárek 1996). Nevertheless, in addition to the dominant cyanobacteria, many other bacteria as well as eukaryotic microorganisms, both photosynthetic (e.g., diatoms) and heterotrophic (ciliates and flagellates) are present in these microbialites, the identification of which deserves further study.

\section{The microbialites}

\section{Previous studies}

The only previous investigation of Alchichica microbialites, along with the identification of associated cyanobacteria, was carried out by Tavera and Komárek (1996). Their report also included basic hydrographical and hydrochemical data on Alchichica based on contributions of other authors. Tavera and Komárek (1996) described and macroscopically illustrated the carbonate deposits occurring almost continuously along the lake shore as underwater structures and structures emerged above lake level. They named the carbonates "stromatolites" and regarded them as structures produced by a variety of cyanobacterial taxa in a specific lake hydrochemistry, characterized by increased salinity and high $\mathrm{pH}$. Tavera and Komárek (1996) noticed that the "stromatolites" occur in Alchichica to the depth of about $12 \mathrm{~m}$ and that their biomats are composed predominantly of cyanobacteria. They identified the following forms as dominant: filamentous (Rivularia $c f$. haematites, Calothrix cf. parietina, Leptolyngbya sp. and Trichormus), and coccoid (Entophysalis atrata and
Entophysalis lithophyla, and less abundant Chroococcidium gelatinosum and Chroococcus schizodermaticus). In addition to these typically benthic forms, Tavera and Komárek (1996) also identified an assemblage of epiphytic cyanobacteria overgrowing the thalli of the filamentous green alga Cladophora sp. The following were also identified: filamentous Heteroleibleinia profunda and Chamaesiphon halophilus, and coccoid Mantellum rubrum and Xenococcus candelariae (comp. Fig. 5).

Tavera and Komárek (1996) distinguished, based on morphological and textural features, three types of "stromatolitic" structures and indicated their locations around the lake: (i) spongy or foamy, (ii) columnar, and (iii) flat crusty. They noticed also a vertical zonal distribution of cyanobacteria and other microorganisms in the distinguished "stromatolites". In their opinion, this zonation is particularly distinct in "stromatolites" forming in shallows and in the splash zone. Here, they described the following zones: (i) black, exposed slightly above water level (up to $30 \mathrm{~cm}$ ), (ii) green, occurring somewhat lower $(10-15 \mathrm{~cm}$ above water level), and (iii) greenish-brown, located slightly below water level. In columnar "stromatolites", Tavera and Komárek did not notice this zonation but described a continuous cover of the brownish coccoid cyanobacteria Entophysalis lithophyla. Tavera and Komárek (1996) did not tackle the microscopic structure of the "stromatolites", their mineralogy and accretion processes.

Macroscopic features of Alchichica microbialites

Due to the lowering of the lake level in the last three decades, an almost continuous belt of carbonate deposits emerged along the lake shore. The largest groups of these microbialites concentrate along the $\mathrm{S}$ and NE shore (Figs. 1 and 2) with their highest points ca. 1.8-2.0 $\mathrm{m}$ above water level. Semicircular groups of dome-like microbialites have cut off several shallow lagoons, which are filled with soft carbonate mud, dark when fresh and white when dried. Inspection by diving found that microbialites with living cyanobacterial mats occur at least to a depth of $14 \mathrm{~m}$.

The emerged (subfossil) microbialites represent two types, differentiated by color and structure (Figs. 2, 8, 9, 10):

(1). "White" microbialites, which occur in the form of massive, almost snow-white large irregular mounds, domes, and crusts without macroscopically visible stratification or lamination (Figs. 8, 10a). Their uneven surfaces are usually ornamented with myriads of rough knobs and granules of various sizes (Fig. 10b). Some of the larger domes have at the center of their bases holes (Fig. 10a) or central canals making them look like to capped chimneys. 

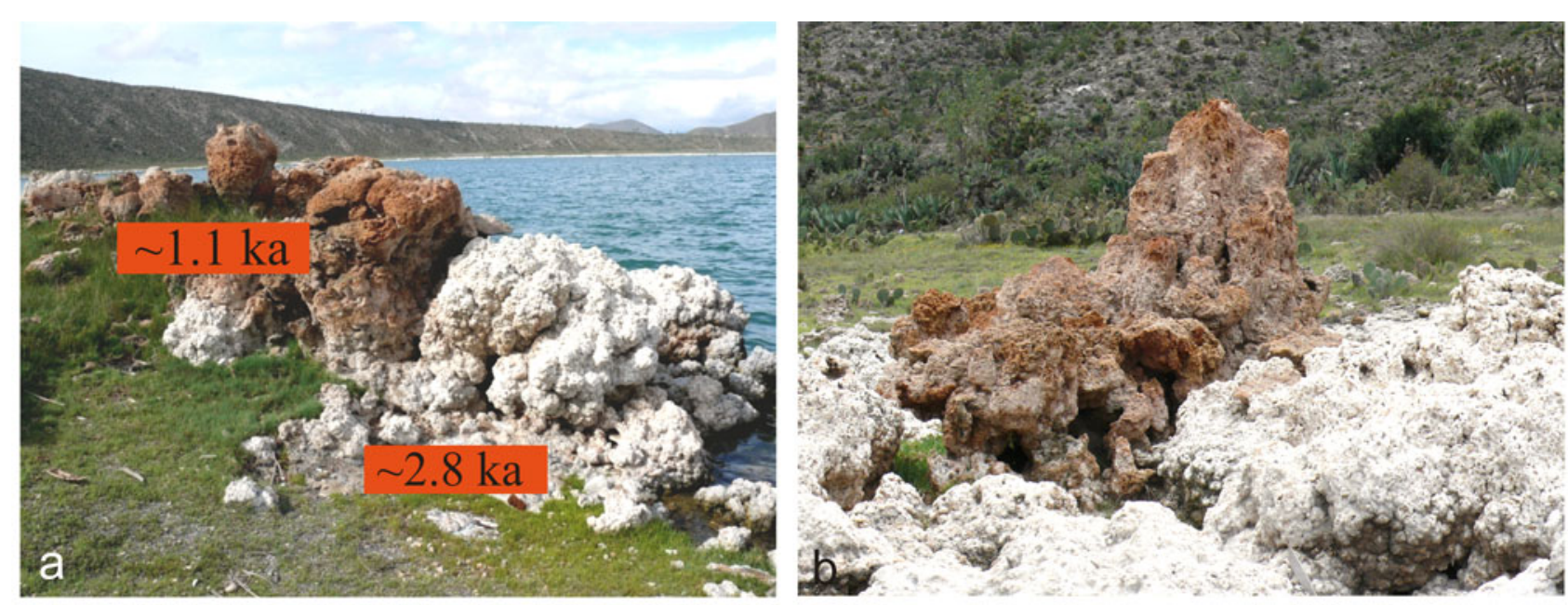

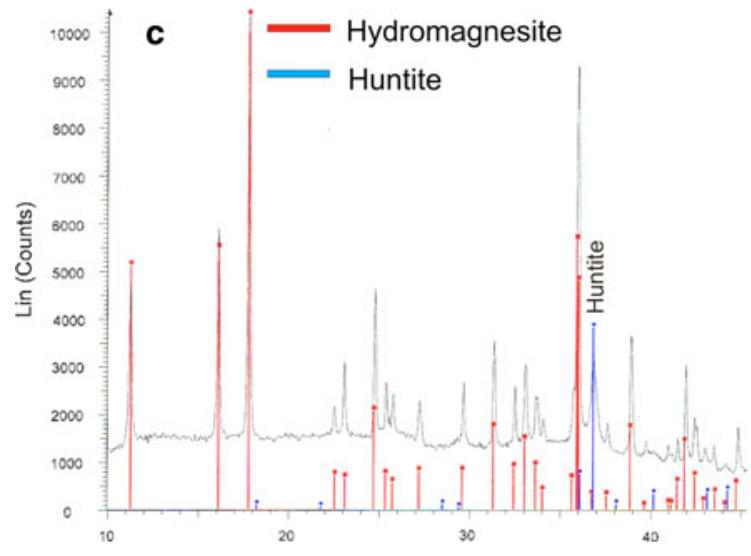

Fig. 8 a, b Field views of subfossil "brown" and "white" generation of Alchichica microbialites emerged above lake level. U-Th radiometric datings of the two basically different microbial carbonate deposits are indicated in (a). $\mathbf{c}$ X-ray diffractogram showing spectra of

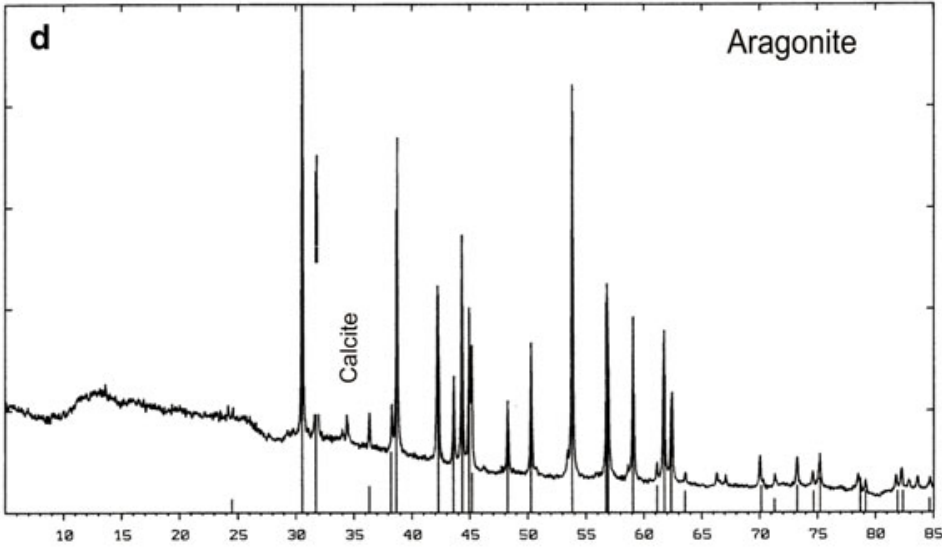

hydromagnesite and huntite typical for the "white" generation of microbialites (sample A-19). d X-ray diffractogram of aragonite (with small admixture of calcite) dominating the "brown" generation (sample A-16)

(2). "Brown" microbialites, which in larger amounts occur on the western shore of the lake and, as isolated groups, in a few other sites. They are in direct contact with the "white" microbialites, and often even overgrowing them (Fig. 8a, b). The "brown" microbialites occur typically as groups of tightly adhering irregular chimney-like structures (Fig. 9a, b) passing laterally into palisade- or candelabra-like columns. Macroscopically, these microbialites have non-laminated, porous, and spongy texture and often a more or less visible central canal in each column (Fig. 9b). A less common variety of the "brown" microbialites are horizontally laminated, $\mathrm{cm}$ to dm-thick crusts, which qualify as stromatolitic structures. The "brown" microbialites occupy, as a rule, sites higher and closer to the crater wall than the "white" microbialites. On the flat onshore terrace they grade into dm-thick encrustations composed of microbially cemented bunches of the vascular water plants Rupia and Cyperus (Fig. 9c-f).

Mineralogy and EDS analyses of Alchichica microbialites

EDS and XRD analyses show distinct differences in the mineral and elemental composition of the "white" and "brown" microbialites. These differences are of importance in understanding microbialite morphogenesis. Differences in mineral phases forming at the contact with the living cyanobacterial mat, as well as diagenetic processes occurring in deeper parts of microbialites, are particularly interesting.

The underwater microbialite samples $(4,8$, and $14 \mathrm{~m})$ were investigated by EDS mapping and EDS spot analysis for $\mathrm{Ca}, \mathrm{Mg}$, and $\mathrm{Si}$ at their contact with the living cyanobacterial mat. In all cases, a $<1$-mm-thick layer rich in $\mathrm{Ca}$ was found. This layer passes downward, either continuously 

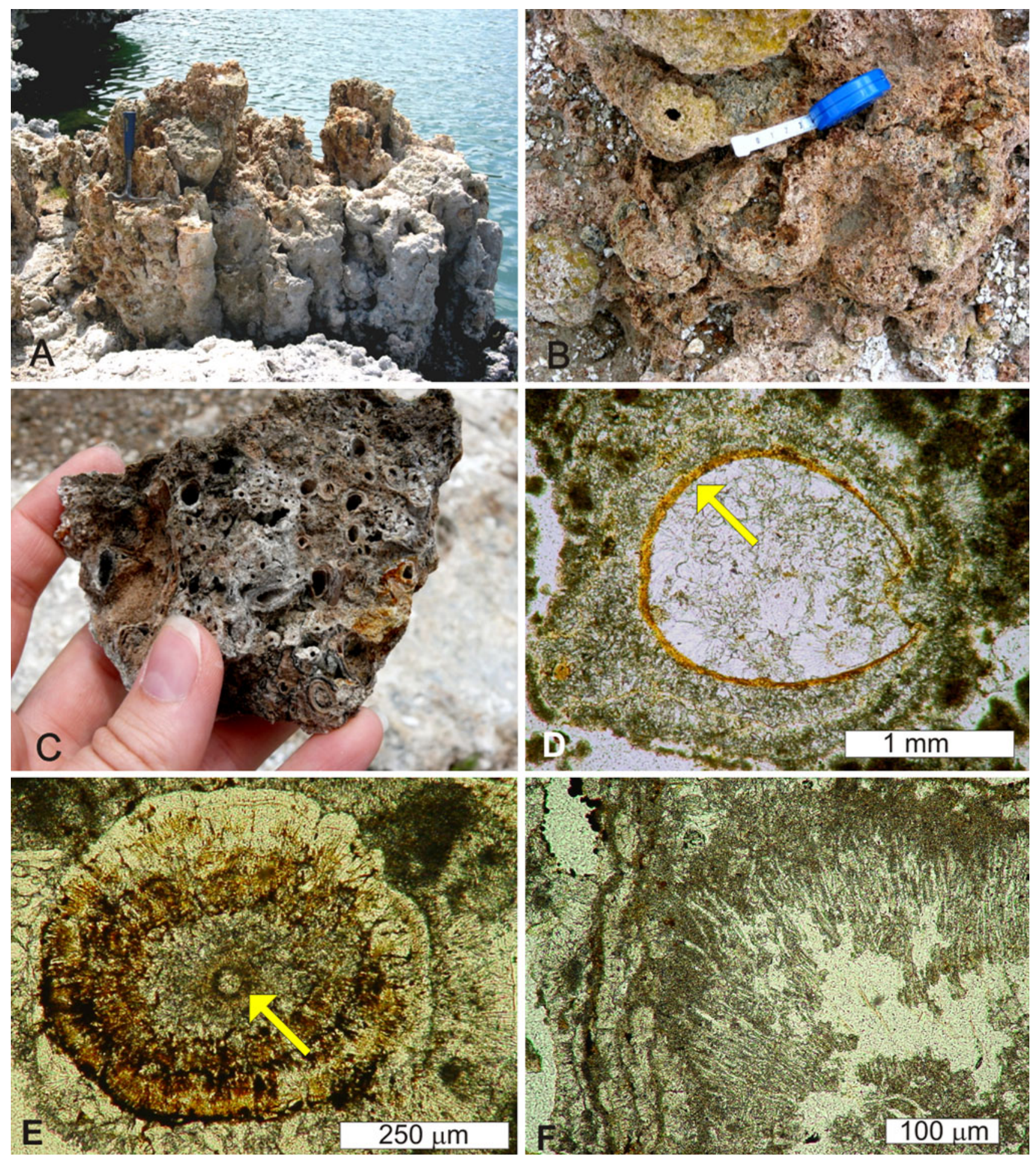

Fig. 9 "Brown" generation of subfossil microbialites emerged above the lake level. a, b Groups of chimney-like aragonitic microbialites formed at ground water inlets on the lake bottom overgrown by vascular water plants (Cyperus and Rupia) and filamentous green algae (Cladophora). c Hand specimen of dense cluster of Cyperus stems cemented with encrusting rivulariacean microbialites. d Cross

section of a Cyperus stem (arrow) encrusted with rivulariacean microbialite. e Cross section of a Cladophora filament (arrow) encrusted with rivulariacean microbialite. f Magnified fragment of rivulariacean microbialite encrusting the stems of water vascular plants and filamentous thalli of green algae. (d-f) are petrographic thin-sections photographed in transmitted light 

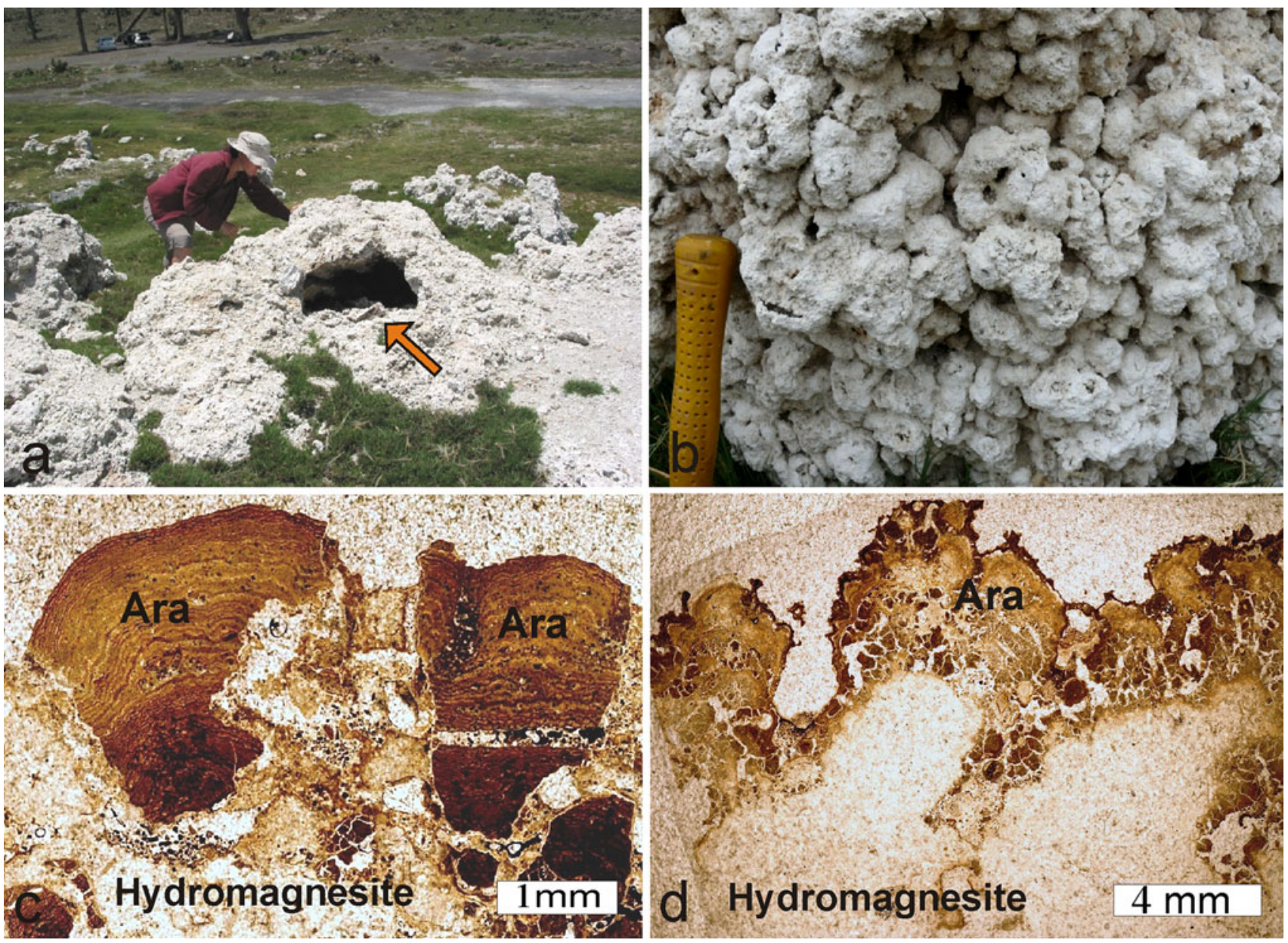

Fig. 10 a Subfossil "white" microbialites emerged above the lake level; note the dome-like microbialite with an orifice (arrow) indicating the point of ground water inflow to the lake. b Closer view of a "white" microbialite knobby surface. c, d Vertical thin

or abruptly into the main mineral microbialite body, which is dominated by $\mathrm{Mg}$ with a varying admixture of $\mathrm{Si}$ (Fig. 11).

$\mathrm{X}$-ray diffractogrammetry (XRD) of the same samples showed that an aragonite layer is precipitated in the living cyanobacterial mat or immediately below it (Fig. 12a-d), which grades downwards into hydromagnesite. The latter (often with a small admixture of huntite) is the main mineral building the "white" microbialites, both those that are currently forming, as well as the emerged (subfossil) ones (Figs. 8, 11). The "brown" microbialites are composed almost entirely of aragonite Fig. 8). Aragonite also cements the volcanic sand occurring between the columnar and the chimney-like "brown" microbialites.

Results of isotope analyses $\left(\delta^{13} \mathrm{C}\right.$ and $\left.\delta^{18} \mathrm{O}\right)$

The stable isotopes values, $\delta^{13} \mathrm{C}$ and $\delta^{18} \mathrm{O}$, measured on microbialite samples (Table 7) show a large variation and sections of the subfossil "white" microbialite showing relicts of its primary microlaminated (i.e., microstromatolitic) texture preserved as aragonite (Ara) within the diagenetic hydromagnesite

a strong covariation $(r=0.95)$. Such strong covariation is most probably associated with evaporative concentration. The values fall into three groups, which have distinct mean values. Lowest values were found in the group of samples from the "brown" microbialites, indicative of a high water level. The group with the next higher mean is that of the "white" build-ups, indicative of a lower water level. The group with the highest values is the one representing the present underwater facies, indicative of the very low water level in the lake at present. The $\delta^{13} \mathrm{C}$ values of calcium carbonate precipitated in vivo by the Alchichica cyanobacterial mats compared with the $\delta^{13} \mathrm{C}$ of the dissolved inorganic carbon (DIC) of the water samples (see Table 7) are heavier by about 3.5-4.5 per mil. This fractionation fits well with $\delta^{13} \mathrm{C}$ shifts $3-6$ per mil between DIC and calcium carbonates reported for other living cyanobacterial mats (Pentecost and Spiro 1990; Merz 1992). 

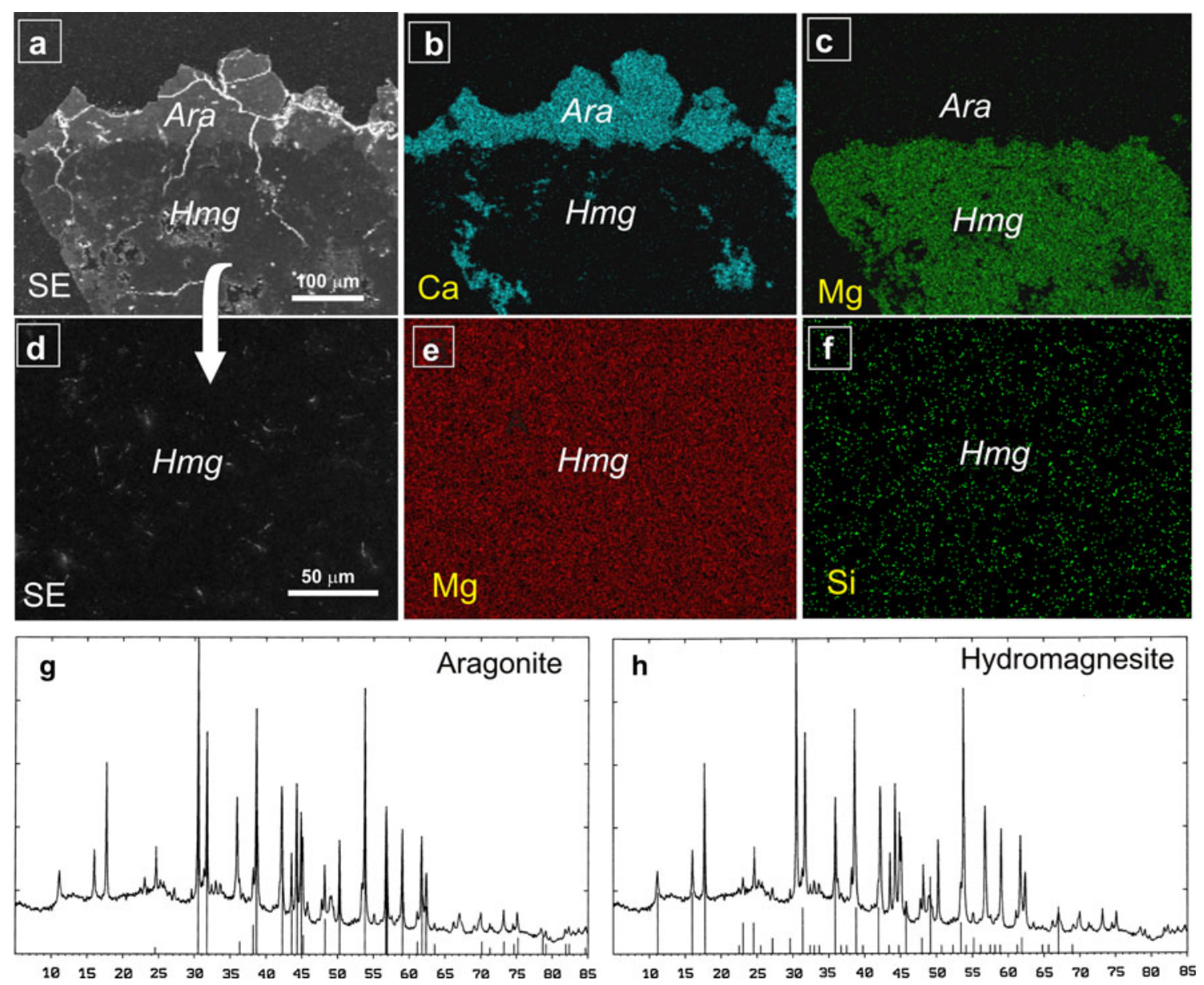

Fig. 11 a SEM image of subsurficial cross section of living cyanobacterial mat taken from c. $4 \mathrm{~m}$ water depth (sample A-48). The topmost part of the section is composed of aragonite (Ara) passing downward into hydromagnesite $(\mathrm{Hmg})$. b, c EDS maps for $\mathrm{Ca}$

and $\mathrm{Mg}$ of the same section. d SEM image of magnified part of the hydromagnesite zone from (a). e, $\mathbf{f}$ EDS maps for $\mathrm{Mg}$ and $\mathrm{Si}$ of the same section. $\mathbf{g}, \mathbf{h}$ X-ray diffractograms of the aragonite (g) and hydromagnesite (h) mineral zones shown above

Radiometric $\left({ }^{238} \mathrm{U} /{ }^{230} \mathrm{Th}\right)$ dating of microbialites

The "brown" and the "white" microbialites were dated by the ${ }^{238} \mathrm{U} /{ }^{230} \mathrm{Th}$ disequilibrium method (Bourdo et al. 2003) (courtesy A. Mangini, Heidelberg). Sample A19 (Heidelberg lab.\# 4729) "white" microbialite yielded a corrected age of $2.81 \pm 0.31 \mathrm{ka}$, and sample A14 (Heidelberg lab.\# 4728) "brown" microbialite yielded a corrected age of $1.128 \pm 0.075 \mathrm{ka}$. These results are in accordance with stratigraphic order, i.e., the "brown" generation is overgrowing the "white" generation. The "brown" facies contains ten times as much $\mathrm{U}\left({ }^{238} \mathrm{U} 1.36\right.$ compared to $\left.0.14 \mu \mathrm{g} \mathrm{g}^{-1}\right)$ and 100 times more ${ }^{232} \mathrm{Th}\left({ }^{232} \mathrm{Th} 25.46\right.$ compared to $0.24 \mathrm{ng} \mathrm{g}^{-1}$ and ${ }^{230}$ Th 0.451 compared to $0.090 \mathrm{pg} \mathrm{g}^{-1}$ ) as the "white" generation, thus illustrating the higher mobilization of $U$ and Th during the "brown" facies in correlation with the highstand of the lake during that time (see below).
Results of microscopic examination of "white" microbialites

The emerged "white" microbialites appear to be identical in texture with those presently mineralizing below water. Petrographic vertical thin-sections of these current microbialites show that below the living cyanobacterial mat, a thin layer of brownish micritic aragonite is present. This layer grades downward into more transparent, i.e., crystalline hydromagnesite (Fig. 12). The micritic aragonite layer is usually indistinctly microlaminated whereas the hydromagnesite is typically almost structureless or irregularly reticulate (Fig. 12a).

Observations of the air-dried surface of the living cyanobacterial films with scanning electron microscopy (SEM) revealed that during the first stages of the mineralization of the mat aragonite nanograins are precipitated in 

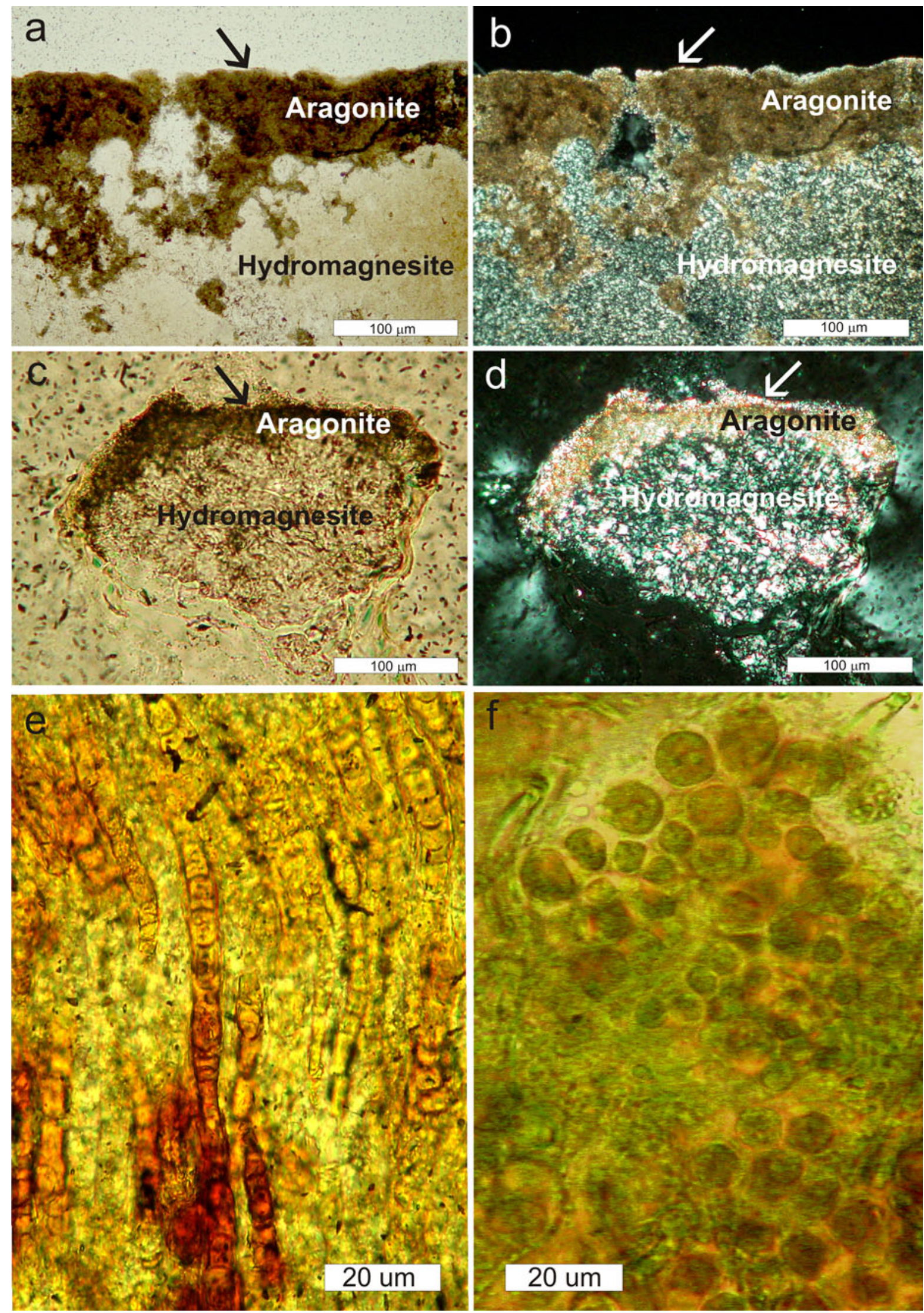
4 Fig. 12 Cross sections of surficial zone of cyanobacterial mats (sample from $8 \mathrm{~m}$ water depth) showing at the top layer of aragonite precipitated by the living mat and below zone of hydromagnesite replacing diagenetically the primary aragonite. a, c Optical micrographs of petrographic thin-sections in plain light. $\mathbf{b}$, $\mathbf{d}$ The same in polarized light to show better the mineralogical differences between the two zones. Arrows indicate mat surface. e, f Remnants of filamentous (e) and coccoid (f) cyanobacteria preserved occasionally in the subsurficial eral matrix. Sample A-45

Table 7 Stable isotope results of different generations of microbialites and water samples of Lake Alchichica (n.d. not determined)

\begin{tabular}{lll}
\hline Sample no. & $\delta^{13} \mathrm{C}$ (vs. VPDB) & $\delta^{18} \mathrm{O}$ (vs. PDB) \\
\hline "White" microbialites & & \\
A16 (subfossil) & 4.7 & 2.05 \\
A22 (subfossil) & 5.71 & 3.79 \\
A11-14(1) (subfossil) & 5.5 & 2.26 \\
Mean & $\mathbf{5 . 3 0}$ & $\mathbf{2 . 7 0}$ \\
Stand. Dev. & $\mathbf{0 . 5 3}$ & $\mathbf{0 . 9 5}$ \\
"Brown" microbialites & & \\
A14 (subfossil) & 1.87 & -1.3 \\
A26(1) (subfossil) & 3.65 & -1.65 \\
A26(2) (subfossil) & 1.76 & -3.78 \\
A26(3) (subfossil) & 1.88 & -3.27 \\
A27 (subfossil) & 1.93 & -2.34 \\
Mean & $\mathbf{2 . 2 2}$ & $-\mathbf{2 . 4 7}$ \\
Stand. Dev. & $\mathbf{0 . 8 0}$ & $\mathbf{1 . 0 5}$ \\
"Modern" microbialites & & \\
A11-14(2) (close to living mat) & 6.01 & 6.36 \\
A48 (close to living mat) & 6.97 & 6.57 \\
Mean & $\mathbf{6 . 4 9}$ & $\mathbf{6 . 4 7}$ \\
Stand. Dev. & $\mathbf{0 . 6 8}$ & $\mathbf{0 . 1 5}$ \\
Water samples & & \\
AL-2 (10-m depth) & 2.37 & 2.04 \\
AL-7 (50-m depth) & & \\
\hline
\end{tabular}

the mucus that is excreted copiously by both the coccoid and filamentous cyanobacteria (Fig. 13).

In older, lower, and partly dead levels of the mats, the aragonite nanograins increase in number and often coalesce into a compact microcrystalline aragonite layer (Fig. 13bd). This coalescence and transformation of aragonite nanograins has been observed both in natural (Kremer et al. 2008) and artificial (Kühl et al. 2003) calcifying cyanobacterial mats.

The early changes of the degree of aragonite crystallinity, in addition to the poorly understood later transformation of aragonite into hydromagnesite, may be associated with volumetric changes causing micro-brecciation and loss of the original microbialite microstructure. This, jointly with biodegradation processes and secondary silicification, has largely destroyed the mat-forming mineralized cyanobacteria. Therefore, morphologically identifiable cyanobacterial remains are extremely rare in the "white" (i.e., hydromagnesite) Alchichica microbialites. Some examples of cellularly preserved filamentous and coccoid cyanobacterial from "white" microbialites are shown in Fig. 12e, f.

Interestingly, occasionally preserved biostructures are a few millimeters thick laminae and groups of cystous structures of almost equal size (Fig. 14a-c). These sparfilled cysts, 50 to $120 \mu \mathrm{m}$ high, are embedded in finegrained (micritic) calcite (Fig. 14a). Irregularly dispersed spheres occur in the cyst walls and in the surrounding sediment (Fig. 14b). These are similar to remains of capsules or sheaths of coccoid cyanobacterial colonies. The cysts may therefore be interpreted as products of coccoid cyanobacteria. They are most probably the remains of forms related to genera Dermocarpella or Dermocarpa, which are known to form such cystous or pillow-like agglomerations. Representatives of these genera occur among the Alchichica cyanobacterial phylotypes (comp. Fig. 7).

These cystous structures are almost identical with cysts described from the subfossil cyanobacterial microbialites found in the quasi-marine crater lake of Satonda Island (Indonesia) that were compared with marine Paleozoic problematic microfossils known as Wetheredella (Kazmierczak and Kempe 1992, 2004). Komárek and Montejano (1994) described cyanobacterial mats from the waterfall El Salto in Mexico that are composed of in vivo calcified hemispherical aggregates of the coccoidal Chlorogloea lithogenes (Dermocarpales) and that also form cystous structures very similar to those from lake Alchichica.

Results of microscopic examination of "brown" microbialites

The "brown" microbialites can be divided into three, often intercalating and alternating, subtypes. These are:

(a) Aragonite-permineralized colonies of the filamentous rivulariacean cyanobacteria. These encrust in thick layers the filamentous thalli of the green alga Cladophora sp. or stems of the vascular water plants Rupia and Cyperus (Fig. 9c-f). The rivularian overgrowths are sometimes interlayered with finely laminated calcareous coatings composed of alternating laminae of micrite and spar. They are very similar to the microstromatolitic encrustations found on filamentous green algae Cladophora, Siphonocladus and Chaetomorpha in Satonda crater lake (Kempe and Kazmierczak 1993, 2007) that are produced by in situ calcified biofilms of coccoid cyanobacteria in an 

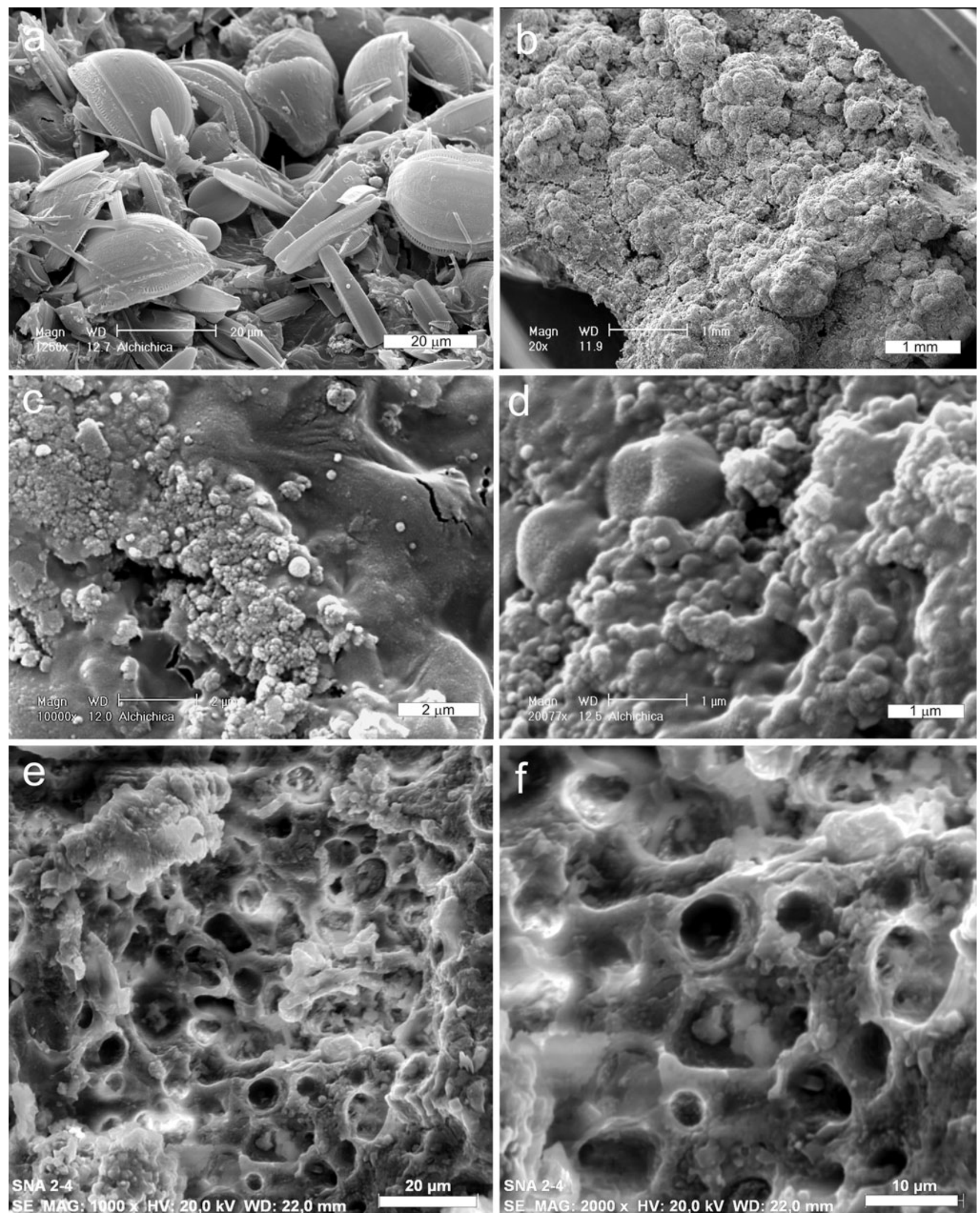

Fig. 13 SEM images of air-dried surface of a living cyanobacterial mat; sample taken from ca. 10-m water depth. a Benthic diatoms cover on the surface of cyanobacterial mat. b, c, $\mathbf{d}$ In vivo precipitated aragonite nanograins in the mucus (EPS) excreted by coccoid

cyanobacteria. e, f Subsurficial cross section of slightly with nanograins calcified common mucus sheaths (glycocalyx) of coccoid cyanobacteria 
Fig. 14 a-c Cystous

microfabrics in subfossil

"white" generation

microbialites in various

magnification. Note the remains

of coccoid cyanobacteria in the

cysts walls (Sample Al IX). d,

e "Brown" subfossil generation of microbialites. Dendroid microbialitic structures reminiscent of the enigmatic

fossil Frutexites Maslov (sample A-28). All vertical thinsections photographed in transmitted plain light
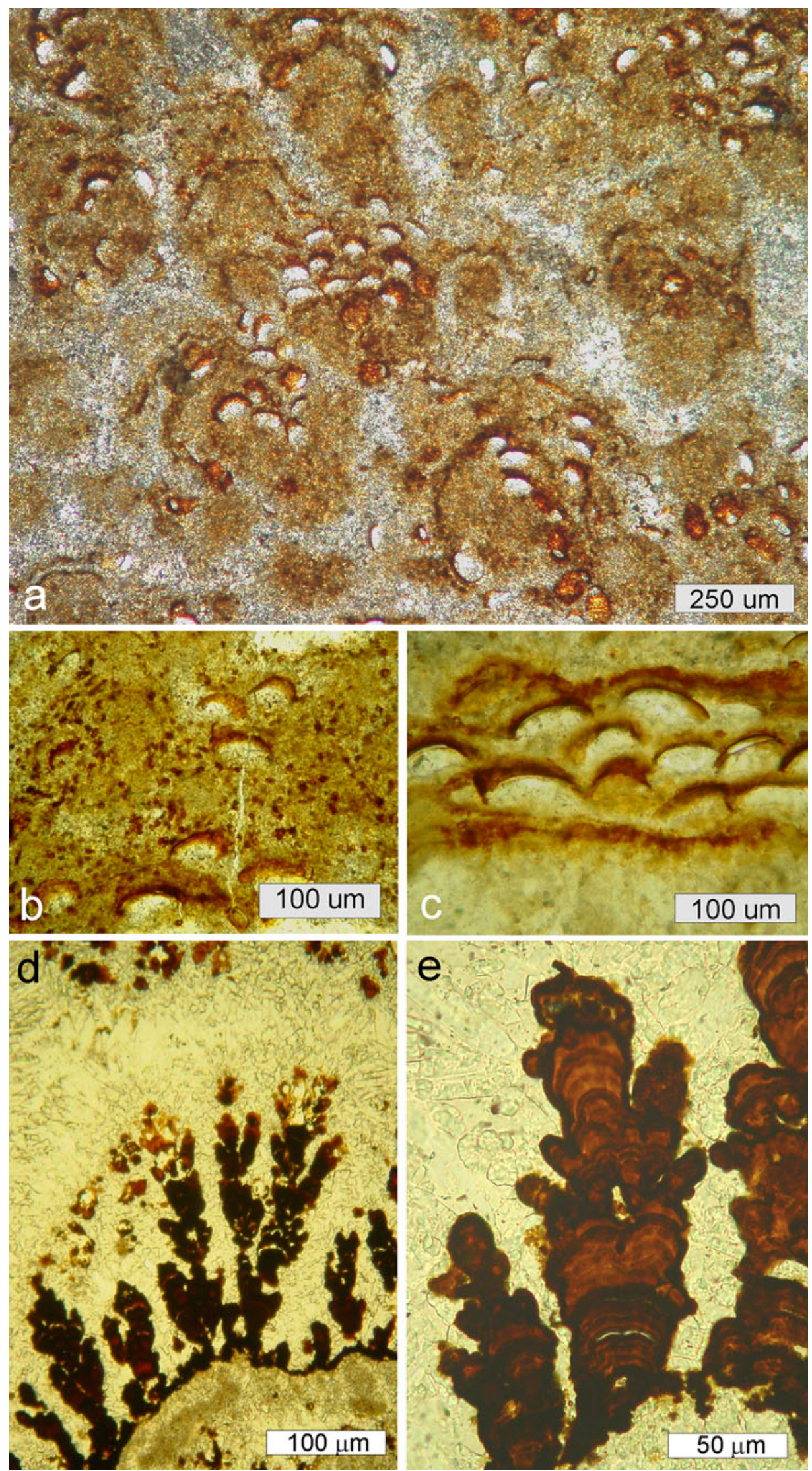

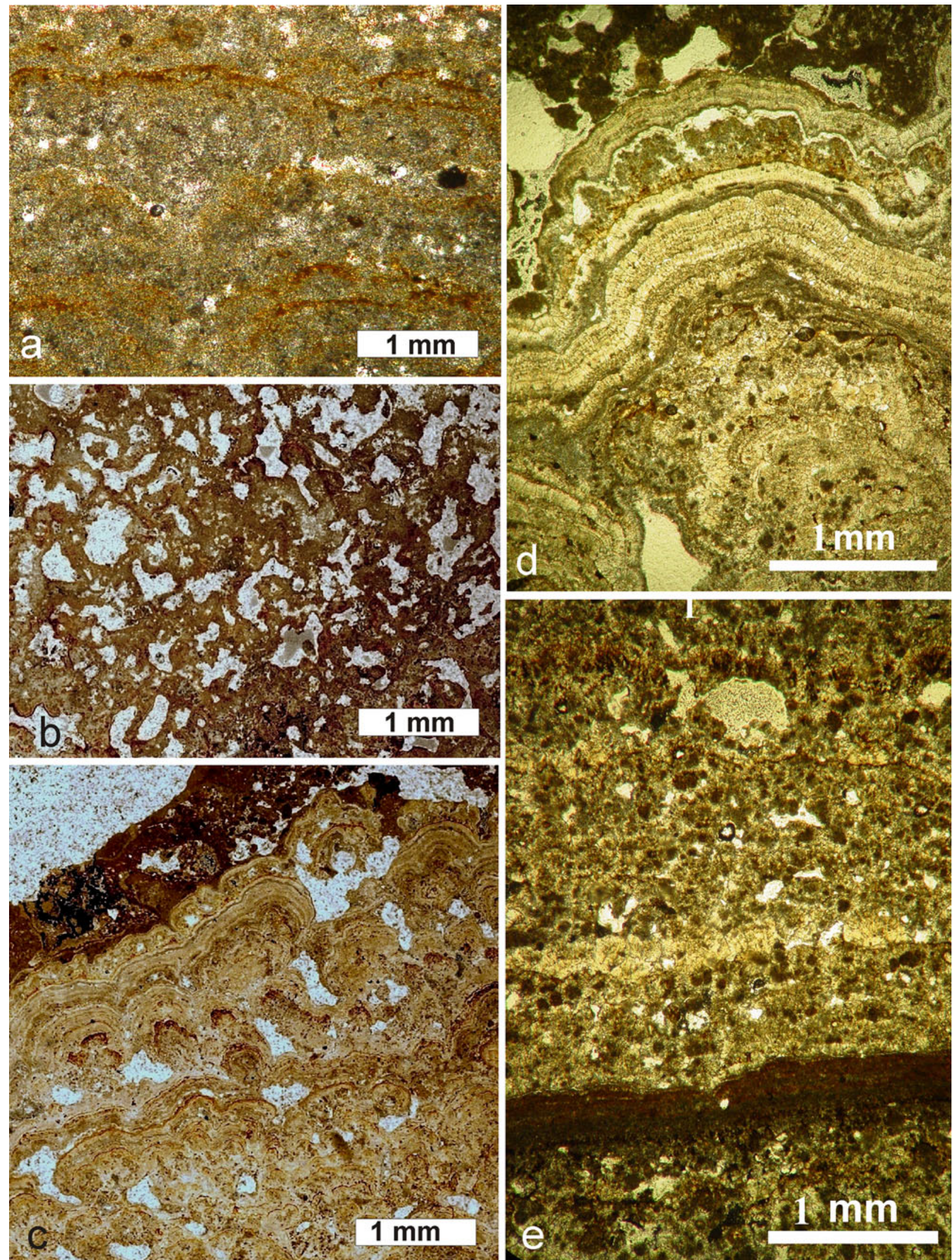
4 Fig. 15 Main types of textures (microfabrics) occurring in the subfossil "brown" generation of Lake Alchichica microbialites. a Clotted (sample A11-14), b fenestrate (sample A-14). c Laminated (microstromatolitic) (sample A-26-1). d Laminated (stromatolitic sensu stricto), texture composed of alternating micritic and sparitic layers (sample A-26). e Laminated texture composed of variously condensed spherulites and peloids (sample A-26). All vertical thinsections were photographed in transmitted plain light

environment similarly supersaturated with calcium carbonate as in Alchichica.

(b) Laminated or fenestrate microbialites: These may occur as: (1) flat or wavy micritic layers composed alternatively of dense and porous micrite and sparite (Fig. 15a); (2) typical fenestrate structures (Fig. 15b), often of "birdseye" type, described from many fossil and modern calcareous microbialites (comp. Flügel 2004); (3) microstromatolites composed of multiple sets of very thin laminae gathered into groups of tiny columns separated by irregular interstitial spaces (Fig. 15c). This group also includes well-layered carbonate sediments that occur in a few isolated points close to the crater wall. Their macroscopic features indicate that they represent highly texturally differentiated stromatolitic bodies that consist of varying proportions of fine-grained and coarse crystalline laminae arranged in systems of flat cones and low columns (Fig. 15d). The fine-grained (micritic) laminae alternate with layers of thrombolitic and peloidal microfabrics (Fig. 15e). These are very similar to those described from Precambrian marine calcareous stromatolites (comp. Hofmann 1975; Hofmann and Jackson 1987; Bertrand-Sarfati 1976; Semikhatov et al. 1979; Buick et al. 1981; Walter 1983; Fairchild 1991; Ginsburg 1991; Knoll and Semikhatov 1998; Riding 2000). Further detailed studies of Alchichica stromatolites may provide interesting information that can help in reconstructing the sedimentary environment and morphogenetic processes that ruled stromatolite formation in Earth's early oceans.

(c) Mn- and Fe-enriched microlaminated dendroid structures: These microbialites, which are almost identical with the problematic fossils known as Frutexites, appear occasionally between laminae of the stromatolites mentioned above. Frutexites are described from the Proterozoic and early Paleozoic strata and they are always associated with stromatolite-bearing sediments (see Horodyski 1975; Walter and Awramik 1979; Myrow and Coniglio 1991). Similar structures were found in subfossil, calcareous microbialites from the caldera lake of Niuafo'ou Island (South-Pacific, Kingdom of Tonga) (Kazmierczak and Kempe 2006). The genesis of these biostructures remains unexplained and the Frutexites-like forms of Alchichica are highly promising in that respect.

\section{Discussion and conclusions}

Our investigation of the Alchichica microbialites yielded several unexpected results. One is the fact that the emerged carbonate build-ups belong to two different generations, i.e., "white" and "brown". These are fundamentally different morphologically, mineralogically, texturally, and isotopically (see Table 7). Radiometric dating showed that the "white" microbialites are older than the "brown" generation. The "white" sample that yielded an age of $2.8 \mathrm{ka}$ BP was selected from the underside of one of the build-ups, and thus represents more or less the beginning of the precipitation in the lake and a minimal age for the formation of the crater itself. The "brown" sample yielded an age of $1.1 \mathrm{ka}$ BP. The "brown" microbialites always overgrow the "white" ones and reach up about $1 \mathrm{~m}$ higher than those, indicating a higher water level. This may be correlated with the medieval climatic optimum when possibly the climate was wetter and the groundwater level was higher. This interpretation is in agreement with the observation that the stable isotope values of the "brown" microbialites are significantly lighter than those of the "white" ones, which is indicative of a less evaporative setting in the lake.

The next unexpected observation is the fact that Alchichica belongs to the few lakes that produce hydromagnesite or hydromagnesite-magnesite microbialites (e.g., Renaut 1993; Braithwaite and Zedef 1994; 1996; Russell et al. 1999; Power et al. 2009). Alchichica's “white" microbialites turn out to be very similar to Holocene stromatolites from the alkaline lake Walyungup in Western Australia (Coshell et al. 1998). In that location, a primary aragonite phase precipitating in the living cyanobacterial film is also diagenetically replaced by hydromagnesite. This fast replacement of aragonite by hydromagnesite is one of the most significant discoveries in Alchichica and it will be subject to further studies. In our opinion, the process has also a bearing on our understanding of the formation of dolomite, abundance of which is so characteristic for the deposits of the early ocean.

It was also astonishing to note that the current mode of microbialite formation, i.e., the fast diagenetic transformation of aragonite to hydromagnesite is apparently the same as the process that led to the formation of the older "white" generation. The difference is their isotopic composition, with the current under-water specimens being heavier than those of the "white" generation. This seems to be consistent with the current low level of water in the lake, 
which seems to be under more evaporative stress due to limited ground water input.

As expected, molecular phylogenetic analyses of the cyanobacteria living on the recent microbialites revealed a large diversity of these organisms and gave no specific clues at this scale as to which particular taxon or taxa were predisposed to precipitate primary aragonite nanograins, as observed in the living biofilms. As is the case in other in vivo mineralizing cyanobacterial biofilms (e.g., Kühl et al. 2003; Dupraz and Visscher 2005; Altermann et al. 2006; Kremer et al. 2008), the preferred nucleation sites for the nanograins are apparently the polysaccharide sheaths and the extracellular polymeric substances (EPS) excreted in various amounts by all cyanobacteria composing the Alchichica biofilms. However, the identification of specific cyanobacteria favoring mineral precipitation will require further study at a finer scale.

The overall importance of the Alchichica build-ups rests in the fact that they once more illustrate one of the main preconditions, which are necessary to form microbialites. As in the case of Alchichica, the water must have a high carbonate mineral supersaturation associated with alkaline conditions. Due to the fact that microbialites are the only biotic macro-remains known from the Precambrian ocean, Alchichica may be used as a modern analogue for early marine geochemistry. It therefore offers a positive test for the hypothesis of the early soda ocean of Kempe and Degens (1985) who claimed that alkaline hydrochemical conditions are linked to high supersaturations and extracellular precipitation of carbonates leading to the growth of microbialites. High $\mathrm{Mg}$ / $\mathrm{Ca}$ ratios and the formation of hydromagnesite can be also useful to test the soda ocean hypothesis since they potentially help in understanding of the widespread occurrence of Precambrian dolomites.

Acknowledgments H.-V. Henschel (Darmstadt) was an invaluable help during the sampling and recording of echo sounding data in the field. A. Mangini (Heidelberg) is thanked for the U/Th dating. N. Jansen (Darmstadt/Hamburg) constructed the isobaths for the bathymetric map of the lake. R. Brannolte (Darmstadt) conducted the hydrochemical laboratory work. M.-O. Jędrysek (Wrocław University) measured carbon (DIC) isotopes in Alchichica water samples. The rubber dinghy was hired from Expediciones Mexico Verde (Veracruz). We appreciate the divers from Club y Escuela de Buceo Buceta Raya (Mexico City) for SCUBA diving and underwater photographs. A local car repair shop is thanked for lending us a car battery and helping with the repair of the echo sounder. Thanks are also expressed to K. Małkowski, M. Kuźniarski and Z. Strąk (all Warsaw) for the analytical work and technical assistance. A. Kazmierczak (Manchester) kindly read the draft and offered linguistic improvements. Heartfelt thanks are directed to the two anonymous reviewers for their constructive criticism and advice. The research was supported financially by the research grant No. N307 019 31/1519 offered by the Ministry of Science and Higher Education (Warsaw) to JK and by the French CNRS interdisciplinary program Origines des Planètes et de la Vie to PLG. Homing Plus Programme of the Foundation for Polish Science and the A. v. Humboldt Foundation are appreciated for their support to BK.

Open Access This article is distributed under the terms of the Creative Commons Attribution Noncommercial License which permits any noncommercial use, distribution, and reproduction in any medium, provided the original author(s) and source are credited.

\section{References}

Alcocer J (1995) Análisis Holistico de la Comunidad de Macroinvertebrados Bentónicos Litorales de Seis Lagos-cráter con un Gradiente de Salinidad. D.Sc. Thesis. Faculdad de Ciencias, Universidad Nacional Autónoma de México, 106 pp

Alcocer J, Hammer UT (1998) Saline lake ecosystems in Mexico. Aquat Ecosys Health Manag 1:291-315

Alcocer J, Lugo A, Estrada S, Ubeda M, Escobar E (1993a) La macrofauna bentónica de los axalapazcos mexicanos. Acta del VI Congreso Español de Limnologia 33:409-415

Alcocer J, Lugo A, Estrada S, Ubeda M, Escobar E (1993b) Littoral chironomids of a Mexican Plateau athalassohaline lake. Verh Internat Verein Limnol 25:444-447

Alcocer J, Escobar E, Lugo A, Peralta L (1998) Littoral benthos of the saline crater lakes of the basin of Oriental, Mexico. Int J Salt Lake Res 7:87-108

Alcocer J, Lugo A, Escobar E, Sanchez MR, Vilaclara G (2000) Water column stratification and its implication in the tropical warm monomictic Lake Alchichica, Puebla, Mexico. Verh Internat Verein Limnol 27:3166-3169

Altermann W, Kazmierczak J (2003) Archean microfossils: a reappraisal of early life on earth. Res Microbiol 154:611-617

Altermann W, Kazmierczak J, Oren A, Wright D (2006) Microbial calcification and its impact on the sedimentary rock record during 3.5 billion years of earth history. Geobiology 4:147-166

Altschul SF, Madden TL, Schaffer AA, Zhang J, Zhang Z, Miller W, Lipman DJ (1997) Gapped BLAST and PSI-BLAST: a new generation of protein database search programs. Nucleic Acids Res 25:3389-3402

Alvarez J (1950) Contribución al conocimiento de los peces de la región de los Llanos, estado de Puebla (México). An Esc Nac Cienc Bio Méx 6:81-107

Armienta MA, Vilaclara G, De la Cruz-Reyna S, Ramos S, Ceniceros N, Cruz O, Aguayo A, Arcega-Cabrera F (2008) Water chemistry of lakes related to active and inactive Mexican volcanoes. J Volcanol Geothermal Res 178:249-258

Arredondo JL (1995) Los axalapazcos de la Cuenca Oriental. Puebla. In: De la Lanza G, Garcia JL (eds) Lagos y Presas de México. Centro de Ecologia y Desarollo, México, pp 65-87

Arredondo JL, Vera O, Ortiz AO (1984) Análisis de componentes principales y de cumulos, de datos limnológicos, en el lago Alchichica, Puebla. Biótica 9:23-39

Arredondo-Figueroa JL, Borrego-Enriquez LE, Castillo-Dominguez RM, Valladolid-Laredo MA (1983) Batimetría y morfometría de los lagos "maars" de la cuenca de Oriental, Puebla, México. Biótica 9:23-39

Benzerara K, Menguy N, López-Garcia P, Yoon Tae-Huyn, Kazmierczak J, Tyliszczak T, Guyot F, Brown EJ Jr (2006) Nanoscale detection of organic signatures in carbonate microbialites. Proc Natl Acad Sci USA 103:9440-9445

Bertrand-Sarfati J (1976) An attempt to classify Late Precambrian stromatolite microstructures. In: Walter MR (ed) Stromatolites. Developments in Sedimentology 20. Elsevier, Amsterdam, pp 251-258 
Bisset A, Reimer A, de Beer D, Shiraishi F, Arp G (2008) Metabolic microenvironmental control by photosynthetic biofilms under changing macroenvironmental temperature and $\mathrm{pH}$ conditions. Appl Environ Microbiol 74:6306-6312

Bourdo B, Simon Turner T, Henderson GM, Lundstrom CC (2003) Introduction to U-series geochemistry. Rev Mineral Geochem 52:1-21

Braithwaite CJR, Zedef V (1994) Living hydromagnesite stromatolites from Turkey. Sedim Geol 92:1-5

Braithwaite CJR, Zedef V (1996) Hydromagnesite stromatolites and sediments in an alkaline lake, Salda Gölü, Turkey. J Sedim Res 66:991-1002

Brandon RA, Maruska EJ, Rumph WT (1981) A new species of neotenic Ambystoma (Amphibia, Caudata) endemic to Laguna Alchichica, Puebla, Mexico. Bull S Calif Acad Sci 80:112-125

Buick R, Dunlop JSR, Groves DI (1981) Stromatolite recognition in ancient rocks: an appraisal of irregularly laminated structures in an Early Archaean chert-barite unit from North Pole, Western Australia. Alcheringa 5:161-181

Caballero M, Vilaclara G, Rodriguez A, Juarez D (2003) Short-term climatic change in lake sediments from lake Alchichica, Oriental, Mexico. Geofisica Intern 42:529-537

Ceballos JG, Ortega MR, Medina M, Martinez M, Rodriguez LS, Gonzáles S (1994) Análisis Limnológico del Lago de Cuitzeo, Michoacán, México. Universidad Michoacana de San Nicolás de Hidalgo, México, 45 pp

Coshell L, Rosen MR, McNamara KJ (1998) Hydromagnesite replacement of biomineralized aragonite in a new location of Holocene stromatolites, Lake Walyungup, Western Australia. Sedimentology 45:1005-1018

de Buen F (1945) Investigaciones sobre ictiologia Mexicana. I. Atherenidae de aguas continentals de México. An Inst Biol Univ Nal Autón Méx 16:475-532

Dupraz C, Visscher PT (2005) Microbial lithification in marine stromatolites and hypersaline mats. Trends Microbiol 13:429-438

Dupraz C, Visscher PT, Baumgartner LK, Reid RP (2004) Microbemineral interactions: early carbonate precipitation in a hypersaline lake (Eleuthera Island, Bahamas). Sedimentology 51:745-765

Fairchild IJ (1991) Origins of carbonate in Neoproterozoic stromatolites and the identification of modern analogues. Precambrian Res 53:281-299

Flores-Vilella O (1993) Herpetofauna Mexicana. Annotated list of the species of amphibians and reptiles of Mexico. Recent taxonomic changes and new species. Carnegie Mus Nat Hist Spec Publ $17: 1-73$

Flügel E (2004) Microfacies of carbonate rocks. Springer, Berlin Heidelberg New York, p 976

Garzón MA (1990) Caracterización Saprótrofica de los Lagos Cráter de la Región de los Llanos, Pue. Bachellor's thesis. ENEP Iztacala, Universidad Nacional Autónoma de México, México, $101 \mathrm{pp}$

Ginsburg RN (1991) Controversies about stromatolites: vices and virtues. In: Müller DW, McKenzie JA, Weissert H (eds) Controversies in modern geology. Academic Press, London, pp 25-36

Goh F, Allen MA, Leuko S, Kawaguchi T, Decho AW, Burns BP, Neilan BA (2009) Determining the specific microbial populations and their spatial distribution within the stromatolite ecosystem of Shark Bay. ISME J 3:383-396

Grotzinger JP, Knoll AH (1999) Stromatolites in Precambrian carbonates: evolutionary mileposts or environmental dipsticks? Ann Rev Earth Planet Sci 27:313-358

Grotzinger JP, Rothman DH (1996) An abiotic model for stromatolite morphogenesis. Nature 383:423-425
Hammer UT (1986) Saline lake ecosystems of the world. Dr. W. Junk Publishers, Dordrecht, $616 \mathrm{pp}$

Hofmann HJ (1975) Stratiform Precambrian stromatolites, Belcher Islands, Canada: relations between silicified microfossils and microstructure. Amer J Sci 275:1121-1132

Hofmann HJ, Jackson GD (1987) Proterozoic ministromatolites with radial-fibrous fabric. Sedimentology 34:963-971

Holland HD (1984) The chemical evolution of the atmosphere and the oceans. Princeton Univ Press, Princeton, New Jersey, p 582

Horodyski RJ (1975) Stromatolites of the lower Missoula group (middle Proterozoic), belt supergroup, Glacier National Park, Montana. Precambrian Res 2:215-254

Jobb G, von Haeseler A, Strimmer K (2004) TREEFINDER: a powerful graphical analysis environment for molecular phylogenetics. BMC Evol Biol 4:18

Kazmierczak J, Altermann W (2002) Neoarchean biomineralization by benthic cyanobacteria. Science 298:2351 (+online suppl)

Kazmierczak J, Kempe S (1992) Recent cyanobacterial counterparts of Paleozoic Wetheredella and related problematic fossils. Palaios 7:294-304

Kazmierczak J, Kempe S (2004) Microbialite formation in seawater of increased alkalinity, Satonda Crater Lake, Indonesia-discussion. J Sedim Res 74:314-317

Kazmierczak J, Kempe S (2006) Genuine modern analogues of Precambrian stromatolites from caldera lakes of Niuafo'ou, Tonga. Naturwissenschaften 93:119-126

Kazmierczak J, Kempe S, Altermann W (2004) Microbial origin of Precambrian carbonates: lessons from modern analogues. In: Eriksson PG, Altermann W, Nelson DR, Mueller WU, Catuneanu $\mathrm{O}$ (eds) The Precambrian earth-tempos and events. Elsevier, Amsterdam, pp 33-52

Kazmierczak J, Altermann W, Kremer B, Kempe S, Erksson PG (2009) Mass occurrence of benthic coccoid cyanobacteria and their role in the production of Neoarchean carbonates in South Africa. Precambrian Res 172:79-92

Kempe S, Degens ET (1985) An early soda ocean? Chem Geol 53:95-108

Kempe S, Kazmierczak J (1993) Satonda Crater Lake, Indonesia: hydrogeochemistry and biocarbonates. Facies 28:1-32

Kempe S, Kazmierczak J (1994) The role of alkalinity in the evolution of ocean chemistry, organization of living systems and biocalcification processes. In: Doumenge F (ed) Past and present biomineralization processes. Considerations about the carbonate cycle. Bull Inst Oceanogr Monaco, no spec 13:61-117

Kempe S, Kazmierczak J (2007) Hydrochemical key to the genesis of calcareous nonlaminated and laminated cyanobacterial microbialites. In: Seckbach J (ed) Algae and cyanobacteria in extreme environments. Cellular origin, life in extreme habitats and astrobiology, vol 11. Springer, Berlin Heidelberg New York, pp 242-264

Kempe S, Kazmierczak J (2011) Soda lakes. In: Reitner J, Thiel V (eds) Encyclopedia of geobiology. Springer, Berlin Heidelberg New York (in press)

Kempe S, Kazmierczak J, Landmann G, Konuk T, Reime A, Lipp A (1991) Largest known microbialites discovered in Lake Van, Turkey. Nature 349:605-608

Kennard JM, James NP (1986) Thrombolites and stromatolites: two distinct types of microbial structures. Palaios 1:492-503

Knoll AH, Semikhatov MA (1998) The genesis and time distribution of two distinctive Proterozoic stromatolite microstructures. Palaios 13:408-422

Komárek J, Montejano G (1994) Taxonomic evaluation of several Chlorogloea-species (Cyanoprokaryota) from inland biotopes. Algol Stud 74:1-26

Kremer B, Kazmierczak J, Stal LJ (2008) Calcium carbonate precipitation in recent cyanobacterial mats from sandy tidal flats of southern North Sea. Geobiology 6:46-56 
Kühl M, Fenchel T, Kazmierczak J (2003) Growth, structure and calcification potential of an artificial cyanobacterial mat. In: Krumbein WE, Paterson DM, Zavarzin GA (eds) Fossil and recent biofilms - a natural history of life on earth. Kluwer, Dordrecht, pp 77-102

Kühl M, Chen M, Ralph PJ, Schreiber U, Larkum AW (2005) A niche for cyanobacteria containing chlorophyll $d$. Nature 433:820

López-García P, Kazmierczak J, Benzerara K, Kempe S, Guyot F, Moreira D (2005) Bacterial diversity and carbonate precipitation in the giant microbialites from the highly alkaline Lake Van, Turkey. Extremophiles 9:263-274

Lowe DR, Tice MT (2004) Geologic evidence for Archean atmospheric and climatic evolution: fluctuating levels of $\mathrm{CO}_{2}$, $\mathrm{CH}_{4}$, and $\mathrm{O}_{2}$ with an overriding tectonic control. Geology 32:493-496

Lugo A, Alcocer J, Sánchez MR, Escobar E (1993) Trophic status of tropical lakes indicated by littoral protozoan assemblages. Verh Internat Verein Limnol 25:441-443

Macek M, Vilaclara G, Lugo A (1994) Changes in protozoan assemblage structure and activity in a stratified tropical lake. Mar Microb Food Webs 8:53-77

McCrea JM (1950) On the isotopic chemistry of carbonates and a paleotemperature scale. J Chem Phys 18:849-857

Merz M (1992) The biology of carbonate precipitation by cyanobacteria. Facies 26:81-102

Myrow PM, Coniglio M (1991) Origin and diagenesis of cryptobiotic Frutexites in the Chapel Island Formation (Vendian to Early Cambrian) of southeast Newfoundland, Canada. Palaios 6:572-585

Ohmoto H (2004) The Archean atmosphere, hydrosphere and biosphere. In: Eriksson PG, Altermann W, Nelson DR, Mueller WU, Catuneanu $\mathrm{O}$ (eds) The Precambrian earth: tempos and events. Elsevier, Amsterdam, pp 361-403

Parkhurst DL, Thorstenson DC, Plummer LN (1990) PHREEQE-a computer program for geochemical calculations. (Conversion and upgrade of the prime version of PHREEQE to IBM PCcompatible systems by Tirisanni JV, Glynn PD). US Geol Surv Wat Res Invest Rep 80-96:1-197

Pentecost A, Spiro B (1990) Stable carbon and oxygen isotope composition of calcites associated with modern freshwater cyanobacteria and algae. Geomicrobiol J 8:17-26

Philippe H (1993) MUST, a computer package of management utilities for sequences and trees. Nucleic Acids Res 21:5264-5272

Power IM, Wilson SA, Thom JM, Dipple GM, Gabites JE, Southam G (2009) The hydromagnesite playas of Atlin, British Columbia, Canada: a biogeochemical model for $\mathrm{CO}_{2}$ sequestration. Chem Geol 260:295-309

Ramirez-Garcia P, Novelo A (1984) La vegetación acuática vascular de seis lagos- crater del estado Puebla, México. Bol Soc Bot Méx 46:75-88
Ramirez-Garcia P, Vazquez-Gutierrez F (1989) Contribuciones al estudio limnobotanico de la zona litoral seis lagos crater del Estado de Puebla. Anal Inst Cienc Mar Limnol 1:1-22

Reid RP, James NP, Macintyre IG, Dupraz CP, Burne RV (2003) Shark Bay stromatolites: microfabrics and reinterpretation of origins. Facies 49:299-324

Reimer A, Landmann G, Kempe S (2009) Lake Van, Eastern Anatolia, hydrochemistry and history. Aquatic Geochem $15: 195-222$

Renaut RW (1993) Morphology, distribution, and preservation potential of microbial mats in the hydromagnesite-magnesite playas of the Cariboo Plateau, British Columbia, Canada. Hydrobiologia 267:75-98

Riding R (2000) Microbial carbonates: the geological record of calcified bacterial-algal mats and biofilms. Sedimentology 47(Suppl 1):179-214

Russell MJ, Ingham JK, Zedef V, Maktav D, Sunar F, Hall AJ, Fallick AE (1999) Search for signs of ancient life on Mars: expectations from hydromagnesite microbialites, Salda Lake, Turkey. J Geol Soc Lond 156:869-888

Semikhatov MA, Gebelein CD, Cloud P, Awramik SM, Benmore WC (1979) Stromatolite morphogenesis-progress and problems. Can J Earth Sci 16:992-1015

Sprachta S, Camoin G, Golubic S, Le Campion T (2001) Microbialites in a modern lagoonal environment: nature and distribution, Tikehau atoll (French Polynesia). Palaeogeogr, Palaeoclim, Palaeoecol 175:103-124

Swingley WD, Chen M, Cheung PC et al (2008) Niche adaptation and genome expansion in the chlorophyll d-producing cyanobacterium Acaryochloris marina. Proc Natl Acad Sc USA 105:2005-2010

Tavera R, Komárek J (1996) Cyanoprokaryotes in the volcanic lake Alchichica, Puebla State, Mexico. Algol Stud 83:511-538

Taylor EH (1943) A new ambystomid salamander adapted to brackish water. Copeia 3:151-156

Thompson JD, Higgins DG, Gibson TJ (1994) CLUSTAL W: improving the sensitivity of progressive multiple sequence alignment through sequence weighting, position-specific gap penalties and weight matrix choice. Nucleic Acids Res 22:4673-4680

Vilaclara G, Chavez M, Lugo A, Gonzales H, Gaytan M (1993) Comparative description of crater lakes basic chemistry in Puebla State, Mexico. Verh Internat Verein Limnol 25:435-440

Walter MR (1983) Archean stromatolites: evidence of the earth's earliest benthos. In: Schopf JW (ed) Earth's earliest biosphere. Princeton Univ Press, Princeton, pp 187-213

Walter MR, Awramik SA (1979) Frutexites from stromatolites of the Gunflint iron-formation of Canada, and its biological affinities. Precambrian Res 9:23-33 